\title{
LETNERY V STREDOVEKÝCH KOSTOLOCH NA SLOVENSKU. PRÍSPEVOK K STAVEBNÝM DEJINÁM MENDIKANTSKÝCH KLÁŠTOROV
}

\author{
BIBIANA POMFYOVÁ
}

\begin{abstract}
Abstrakt: K viacerým mendikantským kostolom na území Slovenska sa viažu doklady alebo indície o niekdajšej existencii stredovekého letnera. Identifikácia tejto špecifickej architektonickej konštrukcie ale nie je vždy jednoznačná. Závisi od celkovej interpretácie stavebného vývoja kostola, alebo dokonca kláštora (v prípade, ked' nie je jednoznačné, ktorý objekt bol hlavným kláštorným kostolom). Štúdia sa zameriava na tri problémové prípady - stavby františkánov v Bratislave a Slovenskej Lupči a augustiniánov-eremitov vo Vel'kom Šariši. Záverečná čast' sa dotýka problematiky letnerov aj mimo kontext mendikantskej architektúry.
\end{abstract}

Kl'účové slová: letner - kostol - kláštor - sakrálna architektúra - stredovek - Slovensko - žobravé rehole-mendikanti.

Rood screens in medieval churches in Slovakia. A contribution to the building history of mendicant monasteries

Abstract: Several mendicant churches in Slovak territory show evidence and indications of the existence of medieval rood screens. However, the identification of these specific architectural elements is not always clear. It depends on the general interpretation of the building development of a church, or even a monastery (in cases when it is not clear which building was the main monastery church). This study centres on three problematic cases: the constructions of the Franciscans in Bratislava and Slovenská Lupča, and the Augustinians - Eremites in Vel'ký Šariš. The final part touches upon the existence of rood screens outside the context of mendicant architecture.

Key words: rood screen - church - monastery - sacred architecture - Middle Ages - Slovakia - mendicant orders - mendicants.

Od ranokrest’anskej antiky sú v kostoloch doložené zábradlia (cancelli), ktoré ohraničovali priestor okolo oltára $\mathrm{v}$ apside alebo pred apsidou. Najneskôr od karolínskeho obdobia je doložené vyčleňovanie tzv. žalmového, resp. liturgického chóru pred hlavným oltárom pomocou neraz vysokých chórových priečok - išlo o priestor, v ktorom sa schádzala príslušná komunita mníchov alebo klerikov k svojim bohoslužobným, chórovým povinnostiam (hl. konventným omšiam a hodinkám). Za týmto účelom boli od 12. storočia popri konštrukčne jednoduchších priečkach budované aj tzv. letnery, lektóriá (z lat. lectorium - miesto predčítania). Na rozdiel od priečok mali vyvýšené pódium, tribúnu. Vo svojej podstate vznikli zlúčením motívu chórovej priečky a tribúny, pričom výsledkom boli mnohoraké variácie tohto spojenia. Popri primárnej úlohe - priestorovo vymedzit' a pohl'adovo chránit' liturgický chór - plnili aj d’alšie funkcie. Išlo o mnohofunkčné architektonické konštrukcie. Na jednej strane oddel'ovali, na druhej strane zabezpečovali spojenie medzi liturgickým chórom a ostatnou čast'ou kostola a tvorili pohl'adový, umelecky neraz náročne stvárnený východný uzáver „laickej“ lode. Boli miestom dôležitých liturgických, ale aj právnych aktov, či biskupských proklamácií. Miestom slávnostného predčítania z Písma, prijímania oltárnej sviatosti, vystavovania relikvií. Dejiskom posväcovania paliem a ratolestí, svätenia sviečok, ako aj dramatizovaných liturgických hier počas Vel'konočného týždňa. Výnimočne je doložené tiež kázanie z letneru. Pod tribúnou letnera, ale aj na nej boli často umiestňované bočné oltáre. Na tribúne bolo zvykom vystavovat' monumentálny krucifix - neraz v spojení s Oltárom Svätého kríža pod tribúnou alebo pred letnerom. Z neskorého stredoveku pochádzajú aj správy o organoch a speváckych chóroch na tribúne letneru (Schmelzer 2004, 10-11, 142-155).

V medievistickom výskume dlho vládol predpoklad, že letnery sa vyskytovali hlavne v kláštorných a kapitulných kostoloch, či nanajvýš vo vel'kých farských kostoloch, pri ktorých pôsobil aj zbor kanonikov. Novší výskum ukazuje, že išlo o rozšírený prvok aj v „,normálnych“ 
farských kostoloch, pri ktorých nemusela byt’ zriadená združená kapitula (Untermann 1996), a že ich výskyt nebol dokonca vylúčený ani v dedinských kostoloch (Kroesen-Steensma 2004, 173-213).

V rámci kláštornej architektúry predstavujú osobitnú tému letnery v mendikantských kostoloch. Výskyt letnerov v kostoloch žobravých reholí narážal totiž v staršej literatúre na predstavu o pôsobení mendikantov (úzky kontakt s veriacimi) a o ideálnom zjednotenom priestore „kazatel'ského" mendikantského kostola. Posun však nastal aj v týchto interpretáciách. Je zrejmé, že prinajmenšom u dominikánov, vo svojej podstate kanonickej reholi, hrali popri prioritnom zameraní na aktívnu prácu s veriacimi od počiatku primeranú úlohu aj tradičné bohoslužobné, chórové povinnosti, a tým aj požiadavka deliaceho architektonického prvku - či už chórovej prepážky, alebo letnera. S rýchlym procesom klerikalizácie nadobudla svoje odôvodnenie pomerne skoro aj u františkánov, a napokon aj u ostatných žobravých reholí, ktoré nasledovali vzor menovaných dvoch najvýznamnejších (súhrnne a s odkazmi na d’alšiu lit. Pomfyová 2018, 76-77). V mendikantských kostoloch bývali často tzv. halové letnery vstavané v celej šírke lode/lodí. Spravidla mali pod vyvýšeným pódiom priestor zaklenutý viacerými klenbovými pol’ami. Tie sa do lode otvárali arkádami a vytvárali tak rad cibórií či kaplniek s bočnými oltármi (Schmelzer 2004, 64-119, 151).

Letnery boli v stredoveku nepochybne rozšírenou súčastou sakrálnych interiérov. Väčšina $\mathrm{z}$ nich zanikla $\mathrm{v}$ dôsledku zmenených nárokov na sakrálny priestor (hl. potridentskej požiadavky zjednoteného priestoru a nehateného pohl'adu na hlavný oltár). Na území Slovenska sa nezachoval žiaden a tento architektonický prvok sa do vel'kej miery vytratil aj z odborného povedomia. Pri interpretáciách architektonicko-historických a archeologických nálezov sa o ňom preto často vôbec neuvažuje. Zmienky o letneroch boli donedávna či už v publikovanej literatúre, alebo nepublikovanej výskumnej dokumentácii nanajvýš zriedkavé a skôr okrajové, pričom nie vždy sa rozlišovalo medzi letnerom a chórovou priečkou. Určitý obrat, cielené upriamenie pozornosti na problém letnerov priniesla až štúdia Štefana Oriška (2010), v ktorej syntetizoval poznatky a indície či už o doložených, alebo potenciálnych letneroch v mendikantskej architektúre na Slovensku. Určite nie je náhoda, že išlo práve o mendikantské stavby. Mendikanti mali v porovnaní s inými rehol’ami na našom území najväčší počet kláštorov a letnery boli nepochybne aj tu dôležitou súčastou interiérového členenia ich kostolov. Jeden z najpresvedčivejších dokladov priniesol napokon výskum Š. Oriška v kostole klarisiek v Trnave. Okrem tejto stavby obsahuje Oriškova štúdia poznatky a úvahy k d’alším šiestim objektom: Slovenská Lupča - františkáni, Košice - dominikáni, Bratislava - františkáni, Trnava - dominikáni, Bratislava - klarisky, Košice - františkáni.

Nasledujúci príspevok chce nadviazat' na štúdiu Š. Oriška. Zameriava sa na tri stavebné komplexy - kláštory františkánov v Bratislave a Slovenskej L’upči a kláštor augustiniánov-eremitov vo Vel'kom Šariši. Prvým dvom sa s ohl'adom na problematiku letnerov venoval už Š. Oriško, domnievam sa však, že aktuálny stav poznatkov si v ich prípade vyžaduje určitú korekciu (Bratislava - františkáni), resp. zásadnú reinterpretáciu (Slovenská L’upča - františkáni). Tretí objekt (Vel'ký Šariš - augustiniáni-pustovníci) dopĺňa Oriškom evidovaný zoznam mendikantských letnerov o d’alší príklad. Záverečný apendix načrtáva problematiku chórových priečok a letnerov aj mimo kontext mendikantských reholí.

\section{Bratislava, františkáni}

Existenciu stredovekého letnera v kostole bratislavských františkánov predpokladal už Flóris Rómer $(1865,285)$. V texte o bratislavských pamiatkach pri opise františkánskeho kostola konštatoval, že vysoko (takmer $1 \frac{1}{2}$ siahy) nasadené stĺpy svätyne stoja ,pri vítaznom oblúku na zvyškoch niekdajšieho lektória“, ktoré malo byt' zbúrané v neskoršom období počas mnohých prestavieb v dôsledku pustnutia. Rómera k citovanému tvrdeniu podnietila zrejme len jestvujúca architektonická štruktúra triumfálneho oblúka. Malo íst' o podobnú situáciu ako v kostole toho istého rádu, dnes mestskom farskom kostole v Nagyszőllösi (Виноградів / Vinogradiv 
na Ukrajine). ${ }^{1}$ Otázka letnera sa potom nadlho vytratila z opisov a interpretácií architektúry bratislavských františkánov. Až v štúdii z roku 1994 a aj to iba v poznámke naznačil možnú existenciu letnera v bratislavskom kostole Ernő Marosi (1994, 58, pozn. 53), ked’ ho v súvislosti so situovaním veže spomenul spolu s inými mendikantskými kostolmi, ktoré mali na konci lode, v „linii letnera“ situovanú vežu (Keszthely, Szécsény, snád' Újlak), cez ktorú mohol byt’ zabezpečený prístup na tribúnu letnera. Problematiku opät' tematizoval Štefan Oriško (2010, 311-312), pričom podotkol, že letner mohol byt' starší ako veža, ktorá bola ku kostolu pristavaná sekundárne. Oriškove úvahy sa opierali nielen o situovanie veže, ale aj o nové nálezy v oblasti triumfálneho oblúka získané v 90. rokoch 20. storočia počas obnovy kostola a sprievodného archeologického prieskumu. Tieto však otvárajú otázky dvojakého druhu - otázky smerujúce jednak k možnému letneru a jednak k predchodcovi stojaceho františkánskeho kostola. Otázka letnera sa preto $\mathrm{v}$ prípade bratislavských františkánov prelína s problematikou historických a stavebných počiatkov kláštora.

Rok a okolnosti založenia kláštora nepoznáme. Najstaršie zachované písomné pramene z 90. rokov 13. storočia dokladajú už existujúci a fungujúci konvent: v listine z 25. apríla 1296 udelil pécsky biskup odpustky františkánskemu Kostolu sv. Jána Evanjelistu v Bratislave (quicunque festiuitatibus beati Iohannis Apostoli et Euangeliste ad Ecclesiam in honore eiusdem Posonii constructam, CDH, 52-53; Ortvay 1895, 264, pozn. 1). Podl'a listiny bratislavskej kapituly z 27. januára 1297 Alžbeta, vdova po komesovi Kozmovi, odkázala v kostole františkánov (in ecclesia fratrum minorum Posonii) obec Horpo komesovi Petrovi (MES, 400, č. 406). Listinou z 26. marca 1297 vystavil ostrihomský arcibiskup Lodomer svedectvo o slávnostnom vysvätení bratislavského františkánskeho kostola na počest' Panny Márie a zároveň povolil udel'ovat' odpustky vo výročný deň vysviacky - na sviatok Zvestovania Panne Márii (Ecclesiae B. Mariae $V$. ordinis fratrum Minorum de Posonio..., ,... solempniter ad laudem et gloriam diuini numinis et in titulum excellentissime Marie virginis dedicando consecrauit et consecrando dedicauit", „in annuis dedicacionis eiusdem Ecclesie ..."; MES, 400-401, č. 407). Odlišné patrocínium kostola v listinách z rokov 1296 (sv. Jána Evanjelistu) a 1297 (Panny Márie) vyvoláva otázky ohl'adom počiatkov kláštora, pričom tieto otázky a nejasnosti sú ešte umocnené rôznymi údajmi tradovanými v novších literárnych zdrojoch.

Dejiny františkánov z konca 16. storočia, spísané generálnym ministrom rádu Františkom Gonzagom, uvádzajú, že Bratislavský konvent bol „vybudovaný Ladislavom [králom Ladislavom IV.] v roku Vtelenia Pána 1580 [správne má byt' nepochybne 1280] po návrate po porážke českého král'a Otokara [Přemysla Otakara II., porazeného v bitke na Moravskom poli v roku 1278]“ (POSONIENSIS conu. per eundem Ladislaum, cum eodem enno Incarnationis Christi 1580. ab Orhocari Boemorum Regis caede reuerteretur, constructus extitit. Gonzaga 1587, 518). Podobný údaj obsahuje Historia domus, kláštorná kronika, ktorú začal písat' v roku 1709 Ján Kapistrán Sebach, člen a istú dobu gvardián bratislavského konventu. Ten zaznamenal, že kláštor nechal postavit' okolo roku 1280 král' Ladislav IV. Kumánsky (Hudec 1999, 62). Tradíciu o tom, že františkánsky kostol dal postavit' král' Ladislav IV. v roku 1280, zachytil aj Matej Bel citujúc „Thurócziho“ (zrejme neskorostredovekého kronikára Jána z Turca). Bel však vzápätí spochybnil, že by to bol rok založenia kláštora. Ten mal jestvovat’ už za čias Belu IV. (1235-1270). Matej Bel ako hlavný argument uviedol „pohrebnú kaplnku“ (Kaplnku sv. Jána Evanjelistu) na severnej strane kostola, o ktorej si na základe stavebného štýlu myslel, že je o dvesto rokov staršia než kostol, a o ktorej sa vraj aj samotní pátri domnievali, že bola presbytériom staršieho (pôvodného) kláštorného kostola. Z dnešného pohl'adu ide o neakceptovatel'ný argument, kaplnka je nepochybne mladšou prístavbou stojaceho kostola. Bel však spomenul aj iné, zo súčasného pohl’adu závažnejšie argumenty. Jednak „nejaké staré listiny“, ktoré sa mali zmieňovat', že pôvodný chrám mal celkovú dížku 40 krokov. Najmä však zmienku v rakúskej

$1 \mathrm{Na}$ túto dlho nepovšimnutú Rómerovu zmienku o letnere v kostole bratislavských františkánov upozornil v novšej literatúre P. Buday $(2012,32)$. Vo farskom kostole v Nagyszőllősi zostali na triumfálnom oblúku zretel'né stopy konštrukcie letnera, na ktorého tribúnu sa zrejme vstupovalo portálom v severozápadnom rohu svätyne, ku ktorému viedlo vežové schodisko v juhozápadnom kúte dnešnej sakristie. Aktuálna literatúra však kostol ani letner v Nagyszöllősi nedáva do súvisu s františkánmi (Papp 2013). 
leobenskej kronike, podl'a ktorej našlo v kláštore minoritov azyl vel'ké množstvo žien, ked' Bratislavu napadol a plienil Přemysl Otakar II. Následne po týchto argumentoch doplnil Matej Bel domnienku, že sakrálna budova bola vo vojne s Přemyslom Otakarom II. poškodená, potom takmer celé desat'ročie ležala v ruinách, kým dal Ladislav IV. postavit' nový kostol (Bel 1735, 585-586; Tibenský ed. 1984, 55-56).

S Belovou interpretáciou sa stotožnil Theodor Ortvay (1892, 343-347; 1903, 521-522), autor kl'účového viaczväzkového diela o dejinách Bratislavy. Nevychádzal v nich však len z Bela. Citoval aj dejiny „tunajšej“ (uhorskej, Mariánskej) provincie františkánskeho rádu, ktoré vznikli za provinciála Petra Heineggera v roku 1740 a v ktorých sa uvádza, že kláštor bol založený už v roku 1240, avšak nie v meste, ale na predmestí, na vyvýšenine pred Laurinskou (Vavrineckou) bránou (Non in civitate Posoniensi, sed extra Suburbium, extra portam S. Laurentii ad montes habebat suum domicilium). Podl'a tohto zdroja bol kláštor postavený na dnešnom mieste (obr. 1) až po porážke českého krála Přemysla Otokara II., ked' ho vnútri mesta nechal v roku 1280 obnovit' Ladislav IV. Ortvay sa ale k možnosti, že by sa kláštor pôvodne nachádzal na inom mieste než dnes, postavil odmietavo s odôvodnením, že pokial' by františkáni boli pred mongolským vpádom usídlení mimo mesta, ich kláštor by isto nezostal ušetrený mongolského plienenia. Pravdepodobnejšie sa mu zdalo, že kláštor bol od začiatku na súčasnom mieste - tak ako to vyplýva z Belových formulácií a ako to tvrdil aj Jakab Rupp. ${ }^{2}$ Podobne ako Ortvay pochyboval o pôvodne inom umiestnení kláštora už historik Mariánskej provincie Eugen Kóša (Kósa) v diele Antiquarii Provinciae S. Mariae collectanea (Zozbierané starožitnosti Mariánskej provincie) z roku 1777. Skepticky sa staval aj k možnosti jeho existencie okolo roku 1240, hoci pripustil, že františkáni tu mohli byt' usadení okolo roku 1271, ked' ich pôvodný kostol a kláštor zasvätený sv. Jánovi Evanjelistovi zničili vojská Přemysla Otakara II. Tento kostol, ktorý mohol byt' dokonca farským chrámom, mal stát' na mieste terajšej bočnej Kaplnky sv. Jána. Po jeho zničení mal Ladislav IV. na pamiatku vít’azstva nad Přemyslom Otakarom II. postavit' na jeho mieste nový kostol, vysvätený v roku 1297 k úcte Panne Márii (Hudec 2009, 13-14, pozn. 8). Kóša a Ortvay mali teda podobný názor na počiatky kláštora, zhodli sa i v predstave, že Kostol sv. Jána spomínaný v roku 1296 stál na mieste dnešnej bočnej Kaplnky sv. Jána. Avšak Ortvay (1895, 226, 263-264) ho na rozdiel od Kóšu nepovažoval za pôvodný kláštorný, či dokonca farský kostol, ale za bočnú kaplnku, ktorá mala už v roku 1296 stát' na severnej strane jestvujúceho kláštorného kostola.

Kóša i Ortvay odmietli, že by sa kláštor pôvodne nachádzal na inom mieste. V literatúre 19. storočia, ktorej autori vychádzali zo starších podkladov, sa však objavujú viaceré verzie o počiatočnom situovaní kláštora mimo opevneného jadra mesta: okrem návršia pred Laurinskou bránou sa uvádza aj poloha vedl'a cesty do Trnavy, na predmestí sv. Udalrika, či pri Kostole sv. Gottharda v predmestskej osade Széplak (Buday 2012, 30). Ďalšiu, odlišnú verziu zaznamenal bratislavský historik Štefan Rakovský: „Hovorí sa, že dnešný kláštor bol kedysi královským palácom a pre účely konventu bol upravený po tom, čo sa tu usadili mnísi zo Sellendorfu."3

V nadväznosti na tradované údaje pretrvávajú protichodné interpretácie aj v aktuálnej literatúre. Často je v nej d’alej uvádzaná verzia o založení kláštora za Belu IV., poškodení počas vojen s Přemyslom Otakarom II., obnovení z iniciatívy Ladislava IV., ktorý tak naplnil sl'ub daný pred vít’aznou bitkou na Moravskom poli v roku 1278, a dokončení kostola s podporou Ondreja III., ktorý sa v roku 1297 zúčastnil na jeho slávnostnej vysviacke. Neprijali ju však všetci bádatelia. Napr. Václav a Dobroslava Menclovci považovali za najpravdepodobnejšie, že kláštor aj kostol založil až Ondrej III. v súvislosti s udelením mestských privilégií Bratislave v roku 1291 (Mencl-Menclová 1961, 51-52). Zrejme vplyv smerodajných diel M. Bela a T. Ortvaya spôsobil, že moderné historické práce, ktoré sa kláštorom dosial’ zaoberali, nepočítali príliš s možnostou jeho translokácie. Pokial' aj uvažovali o meniacom sa kontexte osídlenia, tak spravidla v rámci dnešnej polohy. Podl’a Jaroslava Bureša $(1965,59-60)$ sa františkáni usadili na periférii,

2 Ortvay sa odvolal na Ruppovo dielo Magyarország helyrajzi története fötekintettel az egyházi intézetekre (Topographische Geschichte Ungarns mit besonderer Berücksichtigung der geistlichen Institutionen), I. Budapest 1870.

3 Rakovszky, István: Pozsony egyházai I. A szentferencziek temploma. In: Magyar Sion (Egyháztörténelmi havi folyóirat), 3, Esztergom 1865, 206, cit. podl'a Buday 2012, 30-31, pozn. 9. Sellendorf (Dedina duši/duchov) bola dedina na mieste Mlynskej doliny v Bratislave, približne v dnešnom areáli SAV na Patrónke. 


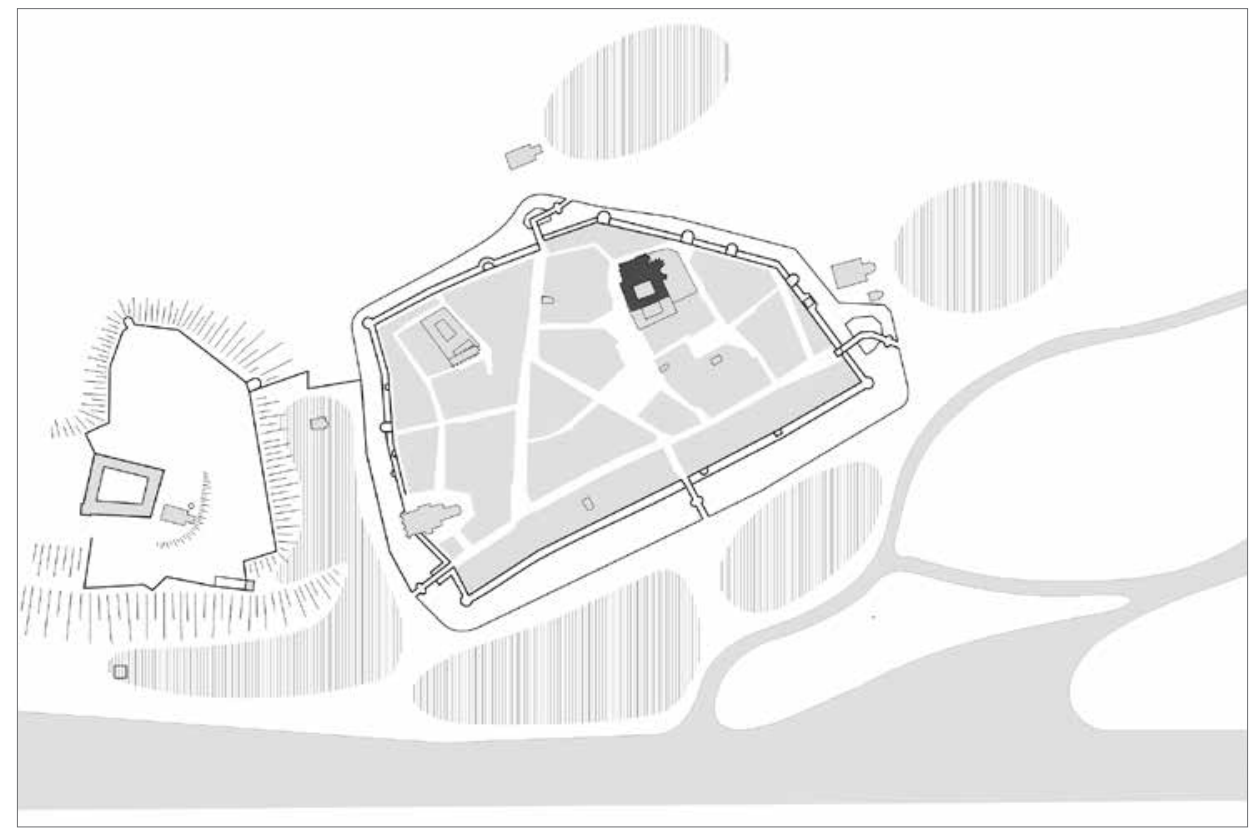

Obr. 1. Bratislava, schematický plán stredovekého mesta so zdôraznenou polohou františkánskeho kláštora. Abb. 1. Bratislava, schematischer Plan der mittelalterlichen Stadt mit hervorgehobener Lage des Franziskanerklosters.

pri sídlisku (podhradskej osade), ktoré postupne nadobúdalo mestský charakter. Podobne mad’arské historičky Judit Majorossy a Katalin Szende (2010, 23), vychádzajúc z údajov v Ortvayovej práci, vyslovili domnienku, že v čase svojho založenia ešte pred mongolským vpádom sa kláštor nachádzal extra suburbium, medzi osadami, ktoré tu existovali pred vznikom mesta, no urbanizáciou nadobudol koncom 13. storočia centrálnu pozíciu na okraji neskoršieho hlavného námestia. Prijali teda tradíciu založenia kláštora pred mongolským vpádom s tým, že nepredpokladali jeho translokáciu, ale zásadnú zmenu významu polohy kláštora uskutočnenú v priebehu 13. storočia: zo suburbia na exponovanú lokalitu v rámci opevneného mestského jadra.

Možnost' translokácie oživil nedávno Rudolf Hudec (2009, 14-18), autor ostatnej monografie o bratislavskom františkánskom kláštore. Aj on predpokladá vznik kláštora pred mongolským vpádom - dokonca už okolo roku 1230, čo sa okrem tradovaných údajov pokúsil doložit' aj d’alšími argumentmi, najmä údajnou prítomnost'ou klarisiek v Bratislave už v druhej polovici 30. rokov 13. storočia, o ktorej by mali svedčit' listiny z rokov 1238 a 1244 . Ked’že vychádza $\mathrm{z}$ toho, že klarisky sa spravidla usádzali v mestách, kde boli františkáni už pevne etablovaní, považuje Hudec skorú prítomnost' klarisiek za dôkaz existencie ,františkánskej stanice“ v Bratislave „prinajmenšom pred rokom 1238“. Menovaný bádatel’ však vo svojej práci vôbec nereflektoval prevažujúcu interpretáciu historikov, ktorí listiny z rokov 1238 a 1244 spájajú nie s klariskami, ale s cisterciánkami (napr. Šedivý 2006, 111). Problematická je aj d’alšia čast' Hudecovej interpretácie, v ktorej tvrdí, že pôvodný kostol františkánov, zasvätený Jánovi Evanjelistovi, nestál na mieste terajšieho kostola, resp. jeho bočnej kaplnky, ako tvrdil rádový historik Kóša, ale na Bratislavskom hrade - malo íst' o prvý prepoštský kostol, zasvätený pôvodne Najsvätejšiemu Spasitelovi a slúžiaci tunajšej kapitule do roku 1221. Hlavný Hudecov argument spočíva v slovnom spojení castrum Posoniensis v listine z 12. novembra 1297 (Ministro Prouinciali Fratrum Minorum Ungariae, Custodi Jauriensi et Guardiano eorundem Fratrum castri Posoniensis), z ktorého má byt' zrejmé, že františkáni v tom čase pôsobili na Bratislavskom hrade, kde mali 
mat' svoj kláštor a kostol. Avšak uvedené slovné spojenie je možné interpretovat' nielen ako hrad Bratislava, ale v danom kontexte takmer s istotou ako (opevnené) mesto Bratislava. Príkladom takého významu slova castrum je zmienka o castrum Judeorum - (opevnenej) židovskej osade v Nitre z roku 1248. V novembri 1297, ked' bola listina vydaná, mali františkáni napokon už pol roka vysvätený dnešný Kostol Panny Márie a najneskôr v tom čase sídlili nepochybne pri ňom. Neobstojí ani argument, že pôvodný kostol nemohol stát' na mieste terajšej Kaplnky sv. Jána, pretože by bránil vo výstavbe nového Kostola Panny Márie. Dejiny architektúry sú plné príkladov kostolov, ktoré boli postupne nahrádzané, niekedy doslova obstavované novostavbou, pričom bola zabezpečená funkčnost' inštitúcie.

Počiatky kláštora tak zostávajú nad’alej neobjasnené. Súhrnne možno konštatovat', že tradované údaje pripúštajú niekol'ko možných scenárov usídlenia sa menších bratov v Bratislave:

1) Kláštor bol založený v/okolo roku 1280 na dnešnom mieste, v nasledujúcich rokoch sa začalo s jeho výstavbou, pričom stavba kostola bola zavŕšená vysviackou v marci 1297.

2) Kláštor bol založený na dnešnom mieste, ale skôr než v/okolo roku 1280, ked’ padlo rozhodnutie o jeho obnove.

3) Kláštor bol založený skôr než v/okolo roku 1280 na inom mieste, v/okolo roku 1280 bol translokovaný na súčasné miesto a začalo sa s jeho novostavbou.

Král'ovská podpora a snád' aj iniciatíva pri založení a následne budovaní kláštora je vel'mi pravdepodobná nielen vzhl'adom na tradované údaje (hlavne vyzdvihovanie úlohy Ladislava IV.), ale aj skutočnost', že v 13. storočí vznikali mendikantské kláštory v Uhorsku predovšetkým s podporou panovníckeho dvora. $V$ prospech možnosti, že kláštor jestvoval a fungoval najneskôr začiatkom 70. rokov 13. storočia, hovorí argument uvedený už Matejom Belom a akceptovaný aj súčasnými historikmi (Šedivý 2006, 115) - sú ním kronikárske záznamy v rakúskych prameňoch (Anonymus Leobensis a Australis historiae pars plenior) o tom, ako v kláštore (ad domum fratrum Minorum) hl'adali útočisko obyvatelia Bratislavy počas útokov Přemysla Otakara II. (1271, 1273-1276). V kontexte známych historických udalostí vyznieva vierohodne tradičné tvrdenie, že pustošivý vpád českého vojska kláštor natol'ko poškodili, že bola nutná jeho zásadná stavebná obnova. Či však pôvodne stál na súčasnom alebo inom mieste, a teda či predpokladanej obnove predchádzala translokácia, zostáva nejasné. S tým súvisia aj otázky ohladom Kostola sv. Jána Evanjelistu, spomínaného v roku 1296, necelý rok pred vysviackou Kostola Panny Márie. Bol to pôvodný kláštorný kostol alebo „len“ bočná kaplnka, ako to chápal Ortvay? Každopádne funkčným kostolom disponovali františkáni aj dva mesiace pred vysviackou, ked’že v januári 1297 poslúžil ako dejisko majetkovoprávneho aktu - testamentárneho odkazu vdovy Alžbety. Kde presne sa odohral, však zrejmé nie je.

Otvorené otázky nepomáhajú zatial' uspokojivo zodpovedat' ani nálezy získané pri obnove kostola v 90. rokoch. Nálezy však minimálne potvrdzujú, že kláštor nevznikol na vol’nom priestranstve. Predchádzalo mu staršie pochovávanie a osídlenie, vrátane staršej zástavby. Do istej miery to môže vysvetl'ovat' nepravidelnosti v pôdoryse kostola: lichobežníkovitú lod' a odlišnú orientáciu pozdížnych osí lode a presbytéria (obr. 2). Vysvetlenie pre vychýlenie osí hl'adal už Jaroslav Bureš (1965, 93-94). Zvažoval dve možnosti, ktoré ho mohli spôsobit' - terénnu situáciu alebo postupnú výstavbu dnešného kostola. Nemajúc dnešné poznatky zavrhol prvú možnost' $\mathrm{s}$ argumentom, že v dobe mestských počiatkov vyrastali žobravé konventy na vol'ných plochách. Priklonil sa tak k druhej možnosti s tým, že kostol mohol byt' pôvodne jednolod'ovou sálou, ku ktorej bolo až dodatočne pristavané presbytérium. Túto možnost' potom ale odmietol Václav Mencl $(1971,254)$, podl'a ktorého bola doba vzniku františkánskeho kostola (pripustil už dobu okolo r. 1270) príliš pokročilá na vznik sálového jednolodia bez presbytéria; lod' aj presbytérium 
kostola považoval napriek osovému vychýleniu za geneticky súvisiace. Ani jeden z nich však zrejme nemal k dispozícii mladšie a presnejšie zamerania kostola, z ktorých vyplýva nielen osové vychýlenie lode a presbytéria, ale i pomerne výrazne lichobežníkovitý pôdorys lode. Súčasné poznatky nás tak opät' vracajú na začiatok problému a nútia nás zvažovat', či dôvodom týchto nepravidelností bola štruktúra staršieho osídlenia, snaha prispôsobit' sa či využit' architektúru, ktorá tu predtým stála, alebo etapovitá výstavba dodnes stojacej architektúry. Menované faktory mohli, samozrejme, pôsobit' súčinne.

Stručná rekapitulácia archeologických dokladov osídlenia lokality: v priestore kláštornej záhrady severovýchodne od kláštornej kvadratúry (na ploche dnešných podzemných garáží na Uršulínskej ul.) bola archeologickým výskumom zachytená čast' vel'komoravského pohrebiska $\mathrm{z}$ druhej polovice 9 . storočia až prvej polovice 10 . storočia a batéria chlebových pecí z 12. storočia (Musilová-Lesák 1996; Lesák-Musilová-Hoššo 1997, 124-127). Na dnešnom rajskom dvore sa zistilo pochovávanie najneskôr do začiatku 17. storočia, pričom čast' týchto hrobov bola s istotou uložená do zeme pred postavením gotickej veže kostola v 14. storočí, ked’že základy veže

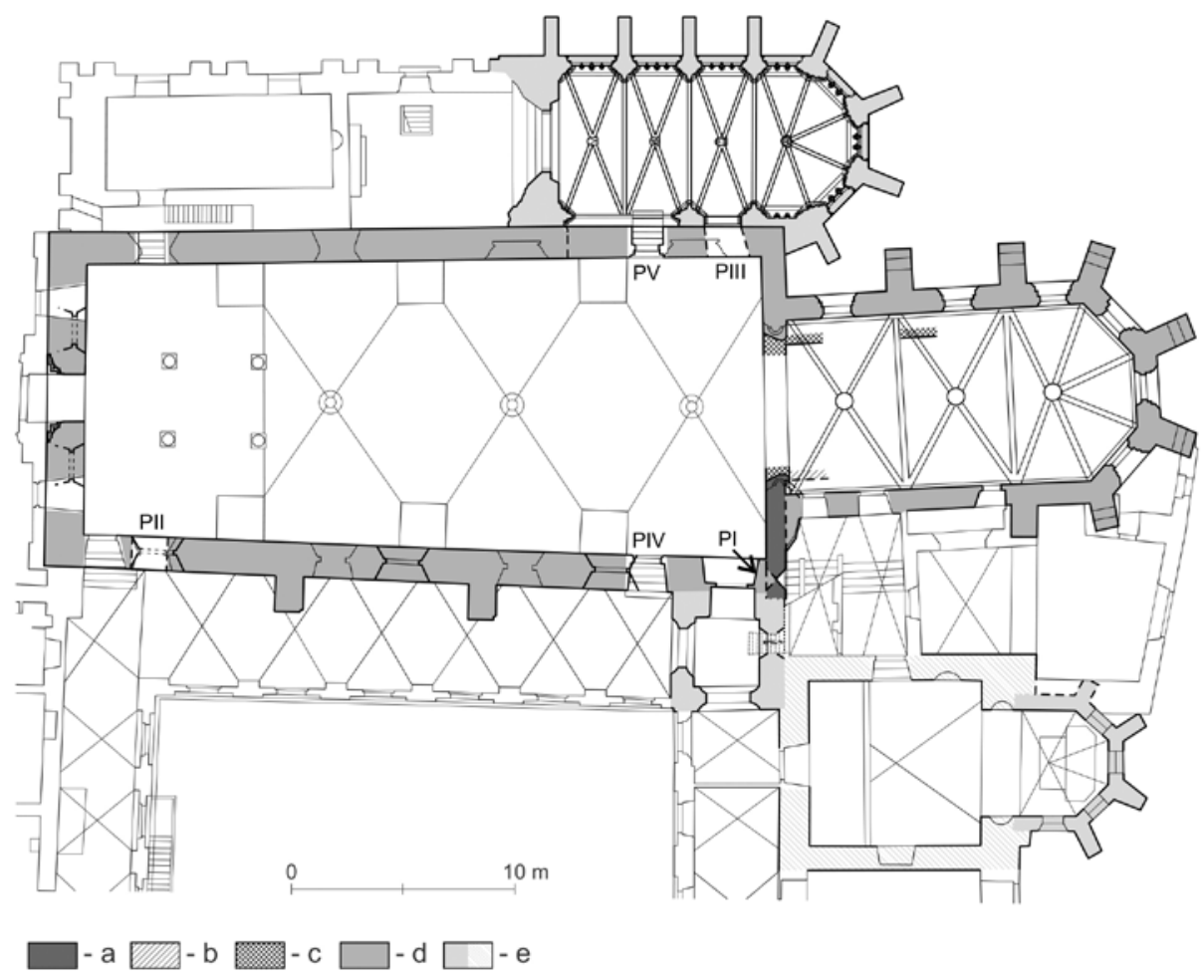

Obr. 2. Bratislava, františkánsky kláštor, pôdorys kostola a pril’ahlých priestorov: a - murivo "A“ (objekt "A“), okolo polovice 13. storočia; b - predpokladané pokračovanie muriva „A“; $\mathbf{c}$ - murivá „B“, približný priebeh a rozsah podl’a podkladov B. Lesáka; d - obvodové múry lode a presbytéria dnešného kostola (vysvätené 1297); e - obvodové múry severnej Kaplnky sv. Jána, južnej veže a Kaplnky sv. Rozálie (14.-15. storočie). P I-PVI - stredoveké portály v bočných stenách lode. Š́pka označuje nález nástennej mal'by s postavou mnícha na ostení portálovej niky. Zdroj Archív Pamiatkového úradu SR, Zbierka projektov a plánov, sign. A6630; upravené, doplnené.

Abb. 2. Bratislava, Franziskanerkloster, Grundriss der Kirche und der angrenzenden Räume. a - Mauerwerk „A“ (Objekt „A“), um Mitte 13. Jhdt.; b - mutmaßliche Fortsetzung von Mauerwerk „A“; c-Mauerwerk, ,B“, annähernder Verlauf und Umfang nach den Unterlagen von B. Lesák; d - Außenmauer des Schiffs und Chorraums der heutigen Kirche (1297 eingeweiht); e - Außenmauer der nördlichen Johanniskapelle, des Südturms und der Rosalienkapelle (14.-15. Jhdt.). P I-PVI mittelalterliche Portale in den Seitenwänden des Schiffs. Der Pfeil kennzeichnet den Fund einer Wandmalerei mit Figur eines Mönches im Gewände einer Portalnische. Quelle Archiv des Denkmalamtes der Slowakischen Republik, Pläne- und Projektsammlung, Sign. A6630; bearbeitet, ergänzt. 
prerezávali staršie hroby (Polla-Vallašek 1991, 46). V južnom krídle dnešného ambitu a juhozápadnom rohu rajského dvora bol zistený sídliskový objekt s mincou Štefana IV. (1133-1165), ktorý bol pretnutý múrom staršej (zrejme stredovekej) krížovej chodby, predchádzajúcej dnešný ambit zo 17. storočia. Aj v týchto miestach boli zachytené zvyšky kostrových hrobov bez datujúcich sprievodných nálezov (Marková 1978; Polla-Vallašek 1991, 45-46). Doklady pochovávania (početné l'udské kosti v zásypoch) sa našli aj v lodi kostola. Najstaršie zistené uloženie kostí predchádzalo stavbe kostola, mladšie patrilo zrejme až do novovekých časových horizontov (resp. do obdobia po prelome 15. a 16. storočia, Resutík 1999, 15). Pred výstavbou dnešného kostola tu jestvoval aj bližšie neurčený objekt, z ktorého pochádzal zvyšok maltovinovej podlahy, zachytený pri západnom úseku južnej steny lode kostola. Podlaha mala síce podobný charakter ako spojivo pôvodného muriva kostolnej lode, avšak ,dokladom časového predstihu položenia dlažby pred stavbou kostola je zretel’ná, asi $5 \mathrm{~cm}$ široká cezúra medzi dlažbou a murivom lode“ (Lesák-Resutík 2000, 75).

Prieskum stien a muriva stojacej gotickej svätyne kostola objavil v jej juhozápadnom kúte, v hmote vysokého sokla triumfálneho oblúka čast' staršieho múru s nárožnou klenbovou konzolou ihlanovitého tvaru, na ktorú prostredníctvom nábežného štítka dosadá fragment klenbového rebra (obr. 5, 6). Pokračovaním tohto múru je s najväčšou pravdepodobnostou stena

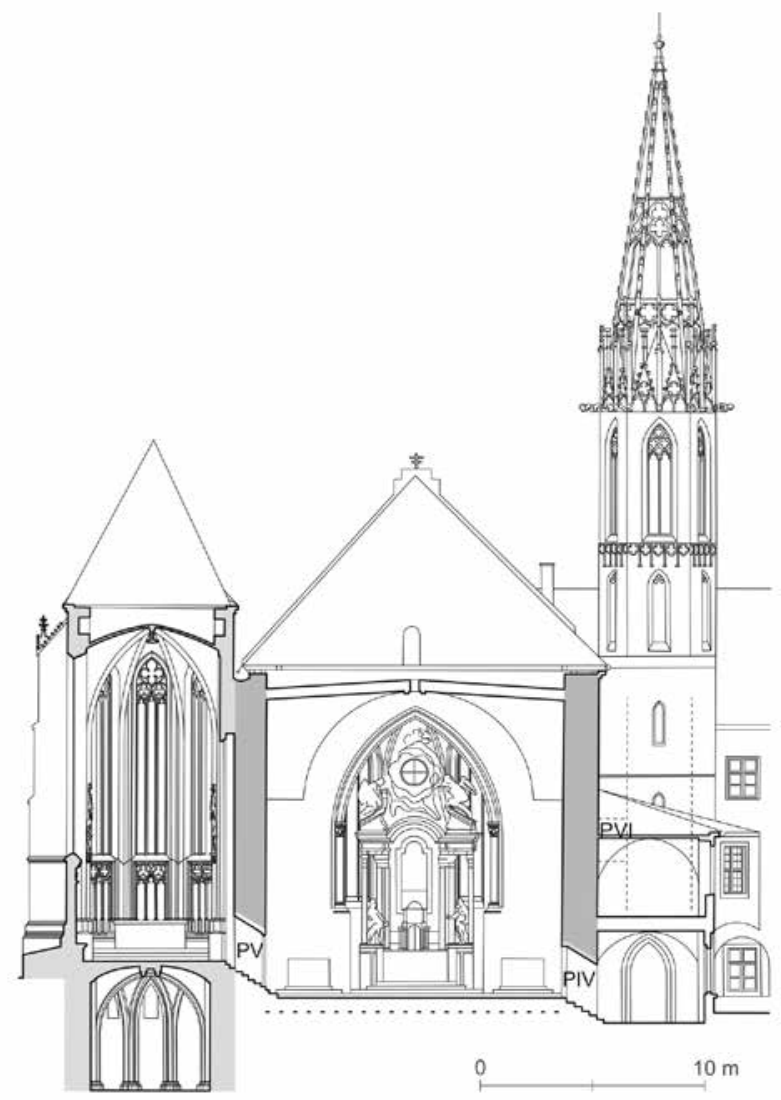

Obr. 3. Bratislava, františkánsky kláštor, východný rezopohl'ad kostola a pril’ahlých priestorov. PIV-PV - stredoveké portály v bočných stenách lode, PVI - stredoveký priechod smerujúci z veže do lode. Zdroj Archív Pamiatkového úradu SR, Zbierka projektov a plánov, sign. A6630, A101; upravené, doplnené.

Abb. 3. Bratislava, Franziskanerkloster, östliche Schnittansicht der Kirche und der angrenzenden Räume. PIV-PV - mittelalterliche Portale in den Seitenwänden des Schiffs, PVI - vom Turm zum Schiff führender mittellalterlicher Durchgang. Quelle Archiv des Denkmalamtes der Slowakischen Republik, Pläne- und Projektsammlung, Sign. A6630, A101; bearbeitet, ergänzt. 
s románskym, štrbinovým, polkruhovo ukončeným oknom v chodbe na južnej strane svätyne. Uvedené architektonické torzo (murivo „A“ na obr. 2) je pozostatkom stavby, ktorá jednoznačne predchádzala výstavbe dnešného kostola. Vymedzovalo zaklenutý priestor, ktorého prevažná čast' sa nachádzala južne od stojacej svätyne kostola. Pre zjednodušenie ho nazvime objektom „A“. Na základe architektonických tvarov konzoly s nábežným štítkom a masívneho hranolového rebra je možné datovat' ho okolo polovice 13. storočia. Stručnú informáciu o náleze publikovala Ingrid Ciulisová $(1998,180,184)$, ktorá počas reštaurátorských prác zastrešovala umeleckohistorickú spoluprácu. Uviedla: „(...) nález (...) tvorí čast’ steny s maliarsky upraveným povrchom, fragmentom konsekračného križa a kamenná hlavica, na ktorú dosadá mohutné hranolové rebro" (Ciulisová 1998, 180). S uvedeným architektonickým torzom teda chronologicky spojila aj fragment mal’ovaného konsekračného kríža nad konzolou. To podmienilo úvahy o objekte „A“ výlučne v kontexte sakrálnej architektúry. Väčšinou sa pritom a priori uvažovalo o súvise s františkánmi. Ciulisová, ktorá prijala tradíciu o založení kláštora za Belu IV. (Ciulisová 1998, 184), vylúčila, že by išlo o kapitulnú sieň alebo letner, a naznačila možnú spojitost' s Kostolom sv. Jána Evanjelistu, spomínaným v roku 1296. Ako určitú alternatívu voči dovtedajšiemu predpokladu, že tento kostol bol predchodcom dnešnej Kaplnky sv. Jána, pripomenula novšie výskumy minoritského kláštora $v$ Levoči, ktoré by mali indikovat’, že zachovanému celku

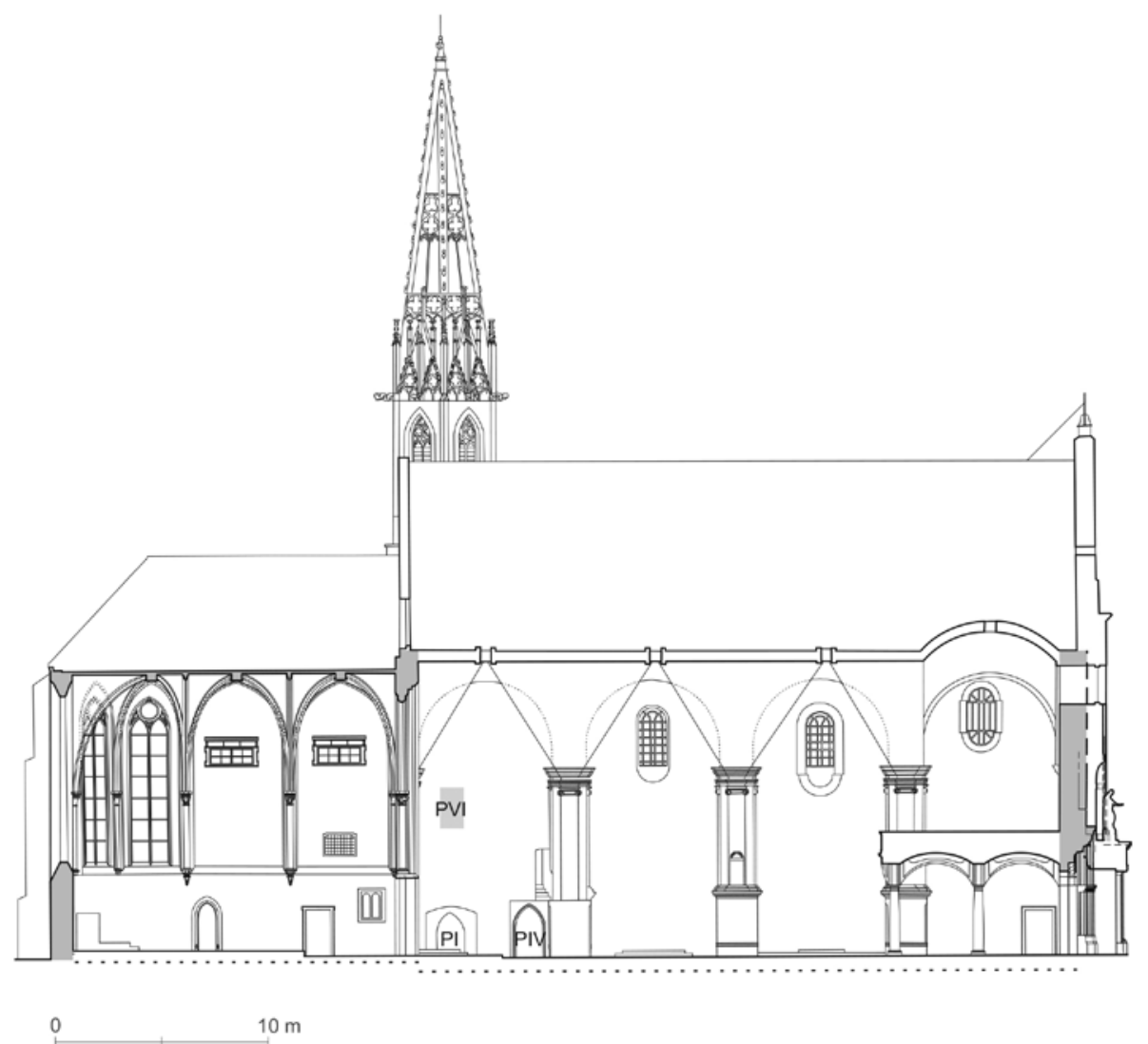

Obr. 4. Bratislava, františkánsky kostol, južný rezopohl’ad. PI-PIV - zachované stredoveké portály v južnej stene lode. PVI - pozícia priechodu smerujúceho z veže do lode. Zdroj Archív Pamiatkového úradu SR, Zbierka projektov a plánov, sign. A6630, Zbierka reštaurátorských dokumentácií, sign. R3727, 3429, 3485; upravené, doplnené.

Abb. 4. Bratislava, Franziskanerkloser, südliche Schnittansicht. PI-PIV - erhaltene mittelalterliche Portale in der Südwand des Schiffs. PVI - Lage des vom Turm zum Schiff führenden Durchgangs. Quelle Archiv des Denkmalamtes der Slowakischen Republik, Pläne- und Projektsammlung, Sign. A6630, Sammlung Restaurierungsdokumentationen, Sign. R3727, 3429, 3485; bearbeitet, ergänzt. 
gotickej architektúry zo začiatku 14. storočia predchádzala staršia kaplnka na mieste neskoršej kapitulnej siene (Ciulisová 2000, 80-81; 2000-2001, 383-384). Naznačila tak možnost', že aj v Bratislave stála staršia sakrálna stavba (Kostol sv. Jána) v priestore neskoršieho východného kláštorného krídla. ${ }^{4}$ Aj Štefan Oriško dal nález do spojitosti s františkánmi. Podl’a neho dokladá, že už pred stojacim kostolom vysväteným v roku 1297 mali bratislavskí františkáni slohovo jasne vyhranenú stavbu (tvaroslovne blízku rakúsko-českej „přemyslovskej stavebnej škole“). Spočiatku uvažoval, že priestor, z ktorého pochádza objavená konzola, mohol byt' starším chórovým uzáverom, či dokonca transeptom (Oriško 2004, 20). Neskôr na rozdiel od I. Ciulisovej pripustil, že môže íst' aj o torzo podklenutého letnera (Oriško 2010, 311-312). Obaja autori a priori vychádzali z predpokladu, že františkáni mali starši kostol na mieste dnešného kláštora. Interpretáciu o staršej sakrálnej stavbe z doby okolo polovice 13. storočia prijala aj autorka tejto štúdie, zdôraznila však, že jej spojitost's františkánmi je otázna vzhl'adom na vyššie uvedené nejasné počiatky kláštora (Pomfyová 2018, 70-71).

Bol však objekt „A“ skutočne sakrálnou stavbou? Potrebné je totiž korigovat’ východisko tohto tvrdenia - chronologický vzt’ah samotného muriva „A“ a fragmentu malovaného konsekračného kríža. Tento sa totiž nachádza $v$ mieste, kde do priestoru vybiehala klenba objektu „A“. Je vylúčené, aby bol konsekračný kríž v dnešnej pozícii súčasný s objektom „A“. Situácia prezentovaná dnes v reštaurovanej svätyni tak pripúšt’a dve možné interpretácie:

1) Mal'ovaný konsekračný kríž primárne patril k objektu „A“, pričom na dnešné miesto sa dostal ako súčast' sekundárne využitého stavebného materiálu z tohto objektu.

2) Prezentované situovanie konsekračného kríža je primárne. $V$ takomto prípade jeho vznik súvisel so zatial' neidentifikovanou stavebnou etapou medzi zánikom objektu „A“ a výstavbou dnešnej svätyne. Zaniká tým dôkaz o sakrálnom charaktere objektu „A“, čím sa diapazón interpretácií rozširuje o možnost', že išlo o profánnu architektúru - meštiansky dom. V takomto kontexte sa zvláśs' zaujímavou stáva tradícia o královskom paláci na mieste dnešného kláštora, ktorú zachytil Š. Rakovský. Stavebná etapa medzi zánikom objektu „A“ a výstavbou dnešnej svätyne nebola zatial' síce identifikovaná, bola však naznačená, ked’ I. Ciulisová $(1998,180,184)$ vo svojej prvej interpretácii predpokladala etapovitú výstavbu dnešného kostola: najprv (po roku 1250) mala byt' postavená lod', na ktorú sa mohla napájat' svätyňa, zničená v česko-uhorských vojnách, následne nahradená súčasnou svätyňou, dokončenou v roku 1297. Uvedená autorka sa tým snažila zdôvodnit' nielen nálezy vo svätyni, ale (v nadväznosti na J. Bureša) aj osové vychýlenie lode a svätyne. Neskôr však konštatovala: „Prieskum zachovanej architektúry potvrdil, že bratislavský františkánsky kostol bol vo svojom gotickom pôdorysnom rozvrhu vytýčený v závere 13. storočia, a to v rámci jednej stavebnej etapy“"(Ciulisová 2000, 78; 2000-2001, 382).

Zmena v interpretácii stavebného vývoja kostola (nie etapovitý, ale jednorázový vznik dnešnej dispozície) nebola zdôvodnená, zrejme však spočívala v odkrytí gotického západného portálu a interiérovej arkatúry v západnej stene lode. Portál svojím štýlom nepochybne korešponduje s architektúrou svätyne a ich datovanie k roku 1297 nevyvoláva žiadne otázky, takže môže viest' k presvedčeniu, že lod' i svätyňa kostola vznikli v celom rozsahu v jednej stavebnej etape. $\mathrm{Z}$ dostupných zdrojov ale nie je zrejmé, do akej miery bola preukázaná primárnost' zmienených architektonických prvkov (západného portálu, arkatúry) voči obvodovým múrom lode, čo opät' vedie k otázke, či obvodové murivo lode predsa len v sebe neskrýva staršiu stavebnú etapu. Túto otázku posilňuje aj situácia, ktorú odkryl archeologický výskum z interiérovej strany západnej steny kostolnej lode. Spodná čast' výklenku gotickej arkatúry (tvorená omietnutým zmiešaným murivom z lomového kameňa a tehál, spájaná svetlou maltou s vysokým obsahom vápna)

4 V prípade Levoče vychádzala autorka z článku F. Javorského (1997-1998, 47). Interpretácie murív, ktoré archeológovia zachytili na mieste bývalej kapitulnej siene levočského kláštora, sú však protirečivé. Pokým F. Javorský a v nadväznosti na neho aj M. Soják a P. Roth (2001-2002) ich považovali za pozostatok staršej sakrálnej stavby, Gabriel Lukáč $(1998,75)$ v nich videl základy polygonálnej svätyne, ktorá sa napájala na kapitulnú sieň zo 14. storočia. Možnost', že by išlo o základy staršej stavby, najnovšie vylúčila N. Urbanová (2018, 133-134) - podl’a nej sú predmetné murivá podmurovkou vyrovnávajúcou skalné podložie, na ktorom bol levočský kláštor postavený. 
spočíva na o $8 \mathrm{~cm}$ užšom murive odlišného charakteru (z neopracovaného kameňa ukladaného do riadkov, spájaného piesčitou maltou), ktoré sa vo svojej spodnej časti rozširuje a v tejto časti má charakter základového muriva. Analogická situácia bola zistená aj v západnej časti južnej steny lode. Opis situácie evokuje dve stavebné etapy, hoci autorom archeologického výskumu (B. Resutík) nebola takto explicitne vyhodnotená (Lesák-Resutík 2000, 74-75). ${ }^{5}$ Možnost' staršej architektúry alebo stavebnej etapy sa tak viaže nielen k priestoru svätyne, ale aj lode.

Vyššie som uviedla dve plauzibilné interpretácie vzt’ahu objektu „A“ a fragmentu mal'ovaného konsekračného kríža vo svätyni. Zodpovedat’ otázku, ktorá z týchto interpretácií je správna, či aspoň pravdepodobnejšia, by v budúcnosti azda umožnil rozbor mált a omietok. Nie je to však jediná otázka ohl'adom stredovekých povrchových úprav stien františkánskeho kostola. Publikovaná interpretácia stredovekej podoby kostola (Ciulisová 1998; 2000; 2000-2001) sa o d’alších stredovekých maliarskych úpravách kostola nezmieňuje (ak opomenieme zmienku o reštaurovaní ranogotickej nástennej výmal'by svätyne, Ciulisová 1998, 180). Avšak v dostupnej nepublikovanej dokumentácii (Flaugnatti-Mýtnik-Ciulisová 1998, nepag.; Flaugnatti-Mýtnik-Ciulisová 1998a, nepag.; Flaugnatti-Mýtnik-Ciulisová 2001, nepag.) je zmienka o viacerých. Za najstaršiu maliarsku úpravu vytvorenú v nadväznosti na vybudovanie obvodových múrov dnešného kostola je považovaná úprava v podobe mal'ovaného iluzívneho sivého kvádrovania. Tento typ výmal'by mal zjednotit’ interiér svätyne aj lode už v prvej etape ich výstavby. V reštaurovanej podobe je dnes prezentovaná vo svätyni, na arkatúrami členenej západnej stene lode, ako aj na portálovej nike a susednom druhom portáli vo východnej časti južnej steny lode. V lodi bola objavená aj stratigraficky staršia vrstva - fragment postavy františkánskeho (?) mnícha na l’avom ostení spomenutej portálovej niky vo východnej časti južnej steny lode (miesto označené šípkou na obr. 2, portál PI na obr. 2, 4). Tento nález však nebol daný do súvisu s obvodovými múrmi lode. Autori dokumentácie zvažovali, že sa mohlo jednat' o „exteriérovú výmal'bu priestoru, ktorého súčast' tvorilo románske okno vedl'a dnešnej sakristie“" (Flaugnatti-Mýtnik-Ciulisová 1998a, nepag.) - teda o exteriérovú mal'bu objektu „A“. Mal'bu ale paradoxne datovali predbežne okolo roku 1300, teda do doby, ked' už podl'a všetkého stál dnešný kostol, vybudovaný sčasti aj na mieste objektu „A“, ktorý v tom čase už nemohol jestvovat' vo svojom pôvodnom rozsahu. ${ }^{6}$ Potvrdzuje to aj terénna situácia zrejmá zo zamerania kláštora: východný úsek južnej steny lode s portálovou nikou a fragmentom mal'ovanej postavy mnícha prekrýva románske okno objektu „A“.7 Mal'ba s postavou mnícha sa teda nemohla viazat’ k objektu „A“. Jestvujúce poznatky opät’ pripúštajú alternatívne interpretácie:

1) Fragment mal'by s postavou mnícha sa viaže k zatial' bližšie neidentifikovanej stavebnej etape medzi zánikom objektu „A“ a výstavbou, resp. dostavbou dnešného kostola.

2) Portálová nika s fragmentom mal'ovanej postavy mnícha je primárnou súčastou dnešného kostola a maliarska úprava $\mathrm{v}$ podobe iluzívneho kvádrovania vznikla prinajmenšom lokálne s väčším časovým odstupom po dostavbe kostola, nie bezprostredne po jeho výstavbe. Samotný portál bol v nepublikovanej dokumentácii vyhodnotený ako sekundárny voči murivu lode, vytvorený mal byt' okolo polovice 14. storočia (Flaugnatti-Mýtnik-Ciulisová 1998a, nepag.). V publikovanej interpretácii je však považovaný za súčast' architektúry kostola už v dobe okolo

\footnotetext{
5 Otázne však opät' je, či potenciálna druhá stavebná etapa nemohla súvisiet’ so sekundárnym vytvorením západnej arkatúry, ktorá bola v publikovanej interpretácii vyhodnotená ako primárna súčast' kostola už v dobe okolo roku 1300.

6 Uvedený paradox mohol vyplynút' z toho, že na rozdiel od publikovaných interpretácií boli v nepublikovanej dokumentácii (FlaugnattiMýtnik-Ciulisová 1998a, nepag.) datované zachované obvodové múry lode až do rozmedzia rokov 1300-1350. Argumentovalo sa formálnou analýzou západného portálu, ako aj nálezmi gotických okien s kružbou. Portál však, ako už bolo zmienené, korešponduje svojím štýlom s tvaroslovím svätyne a dátumom vysviacky v roku 1297. Štýlovo mladšie okenné kružby, ktoré by mohli podnecovat' neskoršie datovanie lode, boli vytvorené a osadené zrejme dodatočne, tak ako predpokladá publikovaná interpretácia (Ciulisová 2000, 80; 2000-2001, 383).

7 Vychádzala som z podrobného zamerania kláštora z roku 1969 v Archíve PÚ SR (sign. A 6630), ktoré som v spolupráci s M. Samuelom (AÚ SAV) preverila kontrolnými meraniami a doplnila o architektonické prvky zistené mladším výskumom.
} 
roku 1300 (Ciulisová 2000, 80; 2000-2001,383). ${ }^{8}$ Rozdiely v interpretáciách naznačujú zložitost' a nejednoznačnost' nálezových situácií. Tá sa zrejme týkala aj vyhodnotenia vrstiev výmal'by. Z dokumentácie (Flaugnatti-Mýtnik-Ciulisová 1998a, nepag., sonda 1) aj prezentovaného stavu je zrejmé, že mal'ba s postavou mnícha bola prevrstvená výmal'bou s iluzívnym kvádrovaním. Otázne však je, ktorou vrstvou tohto typu výmal'by a kedy. Podl'a zistení sondážneho reštaurátorského prieskumu bol totiž interiér lode upravovaný počas stredoveku až sedemnást'krát, pričom prevládala úprava $\mathrm{v}$ podobe sivého iluzívneho kvádrovania s bielymi mal'ovanými linkami, v ktorej sa odlišovala len zvolená vel'kost' kvádrov (Flaugnatti-Mýtnik-Ciulisová 1998a, nepag.). ${ }^{9}$

V publikovanej literatúre sa fragmentu s mal'ovanou postavou mnícha dotkol Š. Oriško (2010, 312). Aj tento nález dal do možnej spojitosti s predpokladaným letnerom - jeho výzdobou. Svoju úvahu bližšie nekonkretizoval, poznamenal len, že mal'ba ,ikonograficky môže predstavovat' jedného z reholných svätcov, jej stav však neumožňuje podrobnejšiu charakteristiku ani datovanie".

Celkovú situáciu d’alej komplikujú archeologické nálezy v oblasti triumfálneho oblúka a skutočnost', že ani tie neboli zatial' podrobnejšie publikované. Zverejnená bola opät' len stručná informácia: „Archeologický prieskum v základovej časti vítazného oblúka d'alej ukázal, že obidve jeho nosné časti boli pravdepodobne v minulosti vzájomne horizontálne prepojené a mohli tvorit' súčast' súvislej exteriérovej steny lode kostola. Neskôr, zrejme pri výstavbe zachovanej svätyne, s ktorou sa mohlo začat' už na začiatku osemdesiatych rokov 13. storočia, boli dolné časti kamenného muriva vit'azného oblúka sekundárne osekané. Vybudovanie spomínanej steny a s tým súvisiace uzatvorenie lode kostola si mohlo vynútit' práve zničenie prvej svätyne a dlhšiu dobu prebiehajúce práce na výstavbe novej“ (Ciulisová 1998, 180). Vo svojej prvej interpretácii, v ktorej pripustila etapovitú výstavbu dnešného kostola, I. Ciulisová teda predpokladala, že počas prestavby svätyne v 13. storočí bola lod' kostola na východnej strane uzavretá plnou stenou. Neskôr, predpokladajúc vznik kostola v jednej etape, uviedla, avšak už bez zmienky o archeologickom náleze $\mathrm{v}$ oblasti triumfálneho oblúka, že k provizórnemu oddeleniu svätyne došlo v 14. storočí v čase zvažovaného zaklenutia lode na stredové piliere (Ciulisová 2000, 80; 2000-2001, 383). Informáciu o preväzujúcom múre v základoch triumfálneho oblúka a jeho osekaných murivách odlišne vyhodnotil Š. Oriško (2010, 311-312), ked' naznačil spojitost' s letnerom. K možnosti, že by išlo o pozostatky letnera, sa na základe publikovaných informácií priklonila aj autorka tejto štúdie (Pomfyová 2018, 101). Opät’ sú však potrebné korekcie, vychádzajúce zo zistení archeologického výskumu.

Archeologické sondy odkryli pri južnom aj severnom sokli triumfálneho oblúka krátke úseky základových murív (murivá „B“ na obr. 2), ktoré mohli, ale aj nemuseli byt' v línii triumfálneho oblúka prepojené do súvislej steny. Výbežok základu na južnej strane bol previazaný so stojacim murivom triumfálneho oblúka. Na severnej strane nebolo previazanie so stojacim murivom jednoznačné, navyše odkrytý úsek základového muriva sa tu pravouhlo zalamoval smerom na východ (za uvedené informácie a konzultáciu d’akujem B. Lesákovi, jednému z autorov archeologického výskumu). Východné pokračovanie tohto múru, rovnobežné so severnou stenou dnešnej svätyne, zachytila aj d'alšia sonda pri severnej stene svätyne (sonda S3/98;

\footnotetext{
8 Okrem hlavného západného portálu a uvedeného portálu vo východnej časti južnej steny lode mala byt' lod' kostola v dobe okolo roku 1300 prístupná d’alšími dvomi portálmi - v západnej časti južnej steny (PII na obr. 2) a vo východnej časti severnej steny lode (PIII na obr. 2). V prípade všetkých troch bočných portálov malo íst' o mohutné portály so segmentovým tehlovým oblúkom. V reštaurovanom interiéri zostal prezentovaný portál vo východnej časti južnej steny lode, ktorý má v hlbokom ostení so segmentovým záklenom vložený ešte kamenný rám, ukončený lomeným oblúkom. Portál v západnej časti južnej steny uvádzajú aj správy z archeologického výskumu - išlo zrejme o „starši zamurovaný vstup z krížovej chodby, situovaný východne od barokového vstupu" (Lesák-Resutík 2000, 74). Existenciu portálu vo východnom úseku severnej steny lode - oproti pertraktovanému južnému portálu - preukázala reštaurátorská sondáž. V nepublikovanej dokumentácii bol rovnako ako jeho južný pendant vyhodnotený ako sekundárny zásah do obvodového muriva z doby okolo polovice 14. storočia (FlaugnattiMýtnik-Ciulisová 1998a, nepag., sonda 47, 48, 50, 51).

9 Fragmenty stredovekej nástennej výmal'by sa však v lodi celkovo zachovali len v minimálnom rozsahu, ked'že väčšina stredovekej omietkovej vrstvy bola odstránená až na kamenné murivo. Zachytáva ich evidovaná dokumentácia a zvyšky sivého kvádrovania sú viditel'né aj v podkroví lode. Legenda k obrazovej časti dokumentácie (Flaugnatti-Mýtnik-Ciulisová 1998a, nepag.) explicitne rozlišuje tri vrstvy stredovekého iluzívneho sivého kvádrovania. Vrstva, ktorá prekrýva figurálnu mal'bu v portálovej nike, bola v rámci relatívnej chronológie bez presnejšieho časového zaradenia vyhodnotená rovnako ako fragment takejto úpravy na protil’ahlom ostení portálu ako sivé iluzívne kvádrovanie 2 .
} 
Lesák-Resutík 2000, 66). Aj tieto murivá sú teda staršie ako stojaca svätyňa. Súvisia ešte s objektom „A“? Alebo - čo sa mi na základe aktuálne dostupných informácí́ zdá byt’ pravdepodobnejšie - sú pozostatkom naznačenej medzietapy po zániku objektu „A“ a pred výstavbou dnešnej svätyne? K zodpovedaniu týchto otázok sú opät' potrebné podrobnejšie informácie o stratigrafii jednotlivých nálezov, charaktere mált, murív aj zachytených fragmentov dlážok. Vo vzt’ahu $\mathrm{k}$ téme tohto príspevku ich však možno vyhodnotit' nasledovne:

Murivo „A“ ani murivá „B“ nepochádzajú z konštrukcie letnera, ale z objektu, resp. objektov, ktoré predchádzali výstavbe dnešnej svätyne. Prinajmenšom v prípade muriva „A“ možno tvrdit', že predchádzalo aj výstavbe dnešnej lode kostola (južná stena lode prekrýva románske okno objektu „A“). Skutočnost', že aj lod' kostola vznikla na mieste starších objektov, indikuje prinajmenšom archeologický nález zvyšku maltovinovej podlahy pri západnom úseku južnej steny lode, ak nie aj archeologicky odkrytá štruktúra muriva západnej a južnej steny. Do akej miery tieto staršie architektonické relikty súvisia s františkánmi, je nejasné jednak vzhl’adom na neistý proces usadenia sa františkánov v Bratislave a jednak na nedoriešené vzájomné vzt'ahy samotných architektonických reliktov (Architektúra predchádzajúca usadeniu sa františkánov na tomto mieste? Architektúra staršia, avšak využívaná františkánmi? Architektúra vytvorená priamo pre františkánov?). Isté však je, že pri stavbe dnešnej svätyne a východných murív lode tieto relikty čiastočne využili, pričom - v prípade murív „B“ v línii triumfálneho oblúka - nie je vylúčené, že ich zakomponovali aj do predpokladaného letneru. Na jeho existenciu poukazujú iné nepriame indície, na ktoré už bolo v doterajšej literatúre upozornené, argumentáciu je však

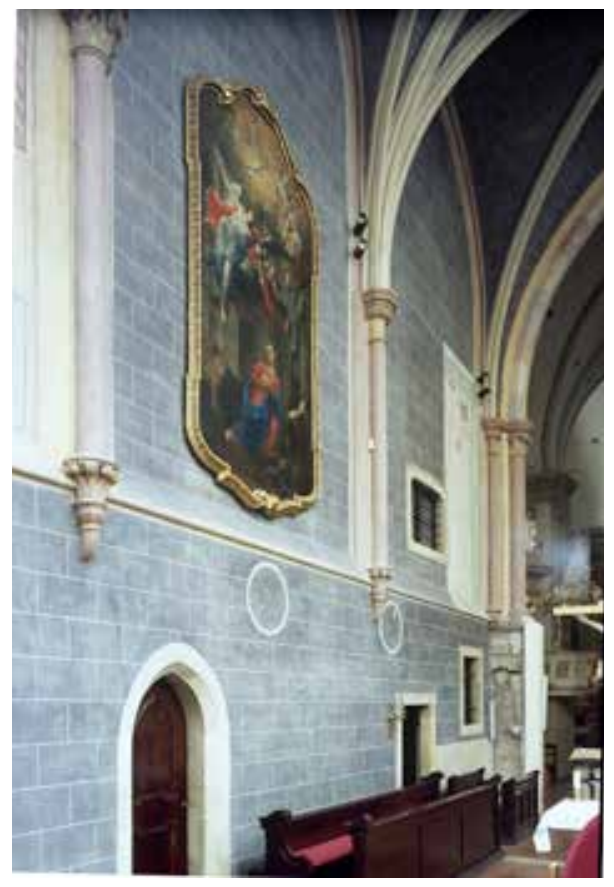

Obr. 5. Bratislava, františkánsky kostol, južná stena presbytéria s triumfálnym oblúkom a nálezom staršieho muriva. Foto P. Breier, Archív Centra vied o umení SAV - Ústavu dejín umenia.

Abb. 5. Bratislava, Franziskanerkloster, Südseite des Chorraums mit Triumphbogen und Fund eines älteren Mauerwerks. Foto P. Breier, Archiv des Zentrums für Kunstwissenschaften der Slowakischen Akademie der Wissenschaften - Institut für Kunstgeschichte.

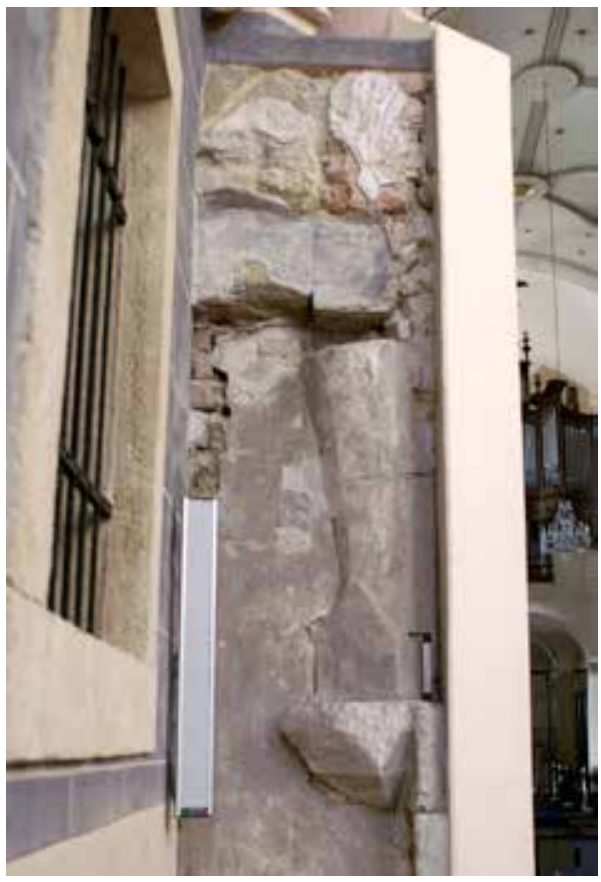

Obr. 6. Bratislava, františkánsky kostol, detail nálezu staršieho muriva (murivo "A“ na obr. 2) s kútovou konzolou, nábehom klenbového rebra a fragmentom mal'ovaného konsekračného kríža. Foto B. Pomfyová.

Abb. 6. Bratislava, Franziskanerkloster, Detail des älteren Mauerwerkfundes (Mauerwerk "A“ auf Abb. 2) mit Eckkonsole, Dienst einer Gewölberippe und Fragment eines aufgemalten Konsekrationskreuzes. Foto B. Pomfyová. 
možné ešte precizovat'. V prvom rade je to vysoká (cca $4 \mathrm{~m}$ ), masívna soklová čast' triumfálneho oblúka. Podobná situácia je vo františkánskom kostole v Levoči, kde je tiež vysoký sokel triumfálneho oblúka jedným z argumentov pre niekdajšiu existenciu letnera (druhým sú dva nad sebou umiestnené okná v južnej stene trojlodia, ktoré mali pôvodne zrejme osvetl'ovat' priestor nad a pod tribúnou letnera, pričom však spodné bolo dodatočne nahradené portálom; Marosi 1974, 301-302). Druhou indíciou v kostole bratislavských františkánov je situovanie veže. Predpoklad, že cez vežu viedol vstup na tribúnu letnera, možno opriet' nielen o jej situovanie „v línii letnera“. Umocňuje ho aj sekundárne zamurovaný portál, ktorý spájal vežu s lod’ou na úrovni prvého poschodia veže (PVI na obr. 3, 4; obr. 7; v dôsledku zmenených podlaží veže sa dnes portál nachádza v úrovni medzi jej prvým a druhým poschodím) ${ }^{10}$ Polkruhovo ukončený portál bol vytvorený v južnej stene lode cca $660 \mathrm{~cm}$ nad stredovekou podlahou v lodi (podla fragmentu podlahy zachyteného v západnej časti lode ${ }^{11}$ ). Analogická situácia sa dochovala vo františkánskom kostole v Keszthely (Mad’arsko, zač. stavby pred 1397), kde na možnú existenciu letnera poukazuje tiež portál vytvorený vo východnom úseku južnej steny lode vo výške empory, ku ktorému prístup zabezpečovalo exteriérové točité schodisko (Anda-Prokopp 1999, 24-25, pôdorys; Tóth 2006). Ďalší príklad sa viaže k františkánskemu kostolu v Szécsényi (Mad’arsko, po 1332). Vstup na tribúnu letnera tu viedol zrejme z poschodia veže, dodatočne postavenej v 15. storočí na severnej strane kostola, kde sa nachádzala (v tom je d'alšia podobnost' so situáciou v Bratislave) kláštorná klauzúra (G. Lászay 1994, 504). Analogické situovanie veže na východnom konci bočnej (južnej) steny lode je pre Š. Oriška $(2010,312-314)$ indíciou existencie letnera aj v prípade dominikánskeho kostola $\mathrm{v}$ Trnave (zaniknutý stav pred vznikom barokového univerzitného komplexu, zachytený na plánoch zo začiatku 17. storočia).

$\mathrm{K}$ zmienenému portálu $\mathrm{v}$ južnej stene lode bratislavského františkánskeho kostola vedie v hrúbke muriva veže krátka chodba so segmentovou valenou klenbou. Či bol portál vytvorený súčasne $\mathrm{s}$ vežou, sa na základe dnešných poznatkov nedá povedat. Každopádne veža bola ku kostolu pristavaná dodatočne, kostol bol pôvodne v zhode s mendikantskými pravidlami bezvežový. Čas jej výstavby nie je úplne jednoznačný. Datovanie sa opiera o štýlové analýzy, súvislosti s bočnou Kaplnkou sv. Jána, aj vežou ned’alekého klariského kostola. Dlhú dobu akceptované datovanie do doby okolo 1400 relativizujú novšie interpretácie Kaplnky sv. Jána i sochárskej výzdoby klariskej veže, ktoré pripúštajú skorší vznik týchto stavieb a tým aj veže františkánskeho kostola snád' už okolo polovice, alebo tesne po polovici 14. storočia. Samotný letner však mohol byt' starší ako veža, čo podotkol už Š. Oriško (2010, 312, pozn. 21). Pokial' pripustíme, že s konštrukciou letnera súvisel vysoký sokel triumfálneho oblúka kostola, potom pripustíme aj to, že s existenciou letnera sa prinajmenšom počítalo už koncom 13. storočia $v$ čase výstavby dnešnej svätyne. Do týchto úvah možno zahrnút' aj prízemnú portálovú niku s fragmentom mal'ovanej postavy mnícha v južnej stene lode (PI na obr. 2, 4), ktorej možnú spojitost's letnerom tiež naznačil už Š. Oriško. Portál v tejto nike (sekundárne zamurovaný) viedol z lode zrejme do priestoru krížovej chodby (jej stredoveký rozsah nepoznáme). ${ }^{12}$ Nápadné je však situovanie niky tesne pri východnom ukončení južnej steny lode, len $30 \mathrm{~cm}$ od juhovýchodného kúta, ktoré mohlo byt' podmienené práve architektúrou letnera. Nika sa nachádza pod zmieneným portálom v úrovni (pôvodného) prvého poschodia veže (PVI na obr. 3, 4). Mohlo íst' teda o portály, ktoré viedli pod a na tribúnu letnera. Prízemný južný portál mal na severnej strane lode pendanta (PIII na obr. 2). Tento severný portál, situovaný taktiež v najvýchodnejšom úseku bočnej steny, ústil spočiatku zrejme do exteriéru, potom do dodatočne pristavanej Kaplnky sv. Jána, ${ }^{13}$ kde mu zodpovedala menšia z dvojice arkád, ktorými sa kaplnka mala otvárat' smerom do lode (obr. 8).

10 Zachytený bol pravdepodobne aj sondami reštaurátorského prieskumu lode kostola, ktoré identifikovali ,gotické okno /?/ v hmote muriva prepájajúceho lod' kostola a vežu“", sekundárne zamurované v ranom baroku (Flaugnatti-Mýtnik-Ciulisová 1998a, nepag., sondy 13 a 14).

11 „Pôvodná maltovinová dlážka slúžiaca od prelomu 13./14. stor. do konca 15. stor. sa nachádzala na úrovni 58 cm“ (Lesák-Resutík 2000, 74).

12 V doterajšej literatúre je charakterizovaný ako vstup do podvežia kostola (Ciulisová 2000, 80; 2000-2001, 383). V čase jeho vzniku - najmä ak akceptujeme existenciu tohto portálu už okolo roku 1300 - veža však ešte nestála. Ani po výstavbe veže neviedol do uzavretého podvežia. Veža sa totiž v prízemí otvárala vysokými, dodnes čiastočne zachovanými arkádami do severného aj východného krídla ambitu. Cez tento portál bolo teda zrejme možné spojenie medzi lod’ou (letnerom?) a krížovou chodbou. Organizácia priestoru sa však mohla menit' ešte v priebehu stredoveku. Otázkou zostáva, kedy bol tento portál zamurovaný.

$13 \mathrm{~K}$ jeho datovaniu pozri pozn. 8. Zamurovaný bol v ranom baroku (Flaugnatti-Mýtnik-Ciulisová 1998a, nepag., sondy 50, 51). 


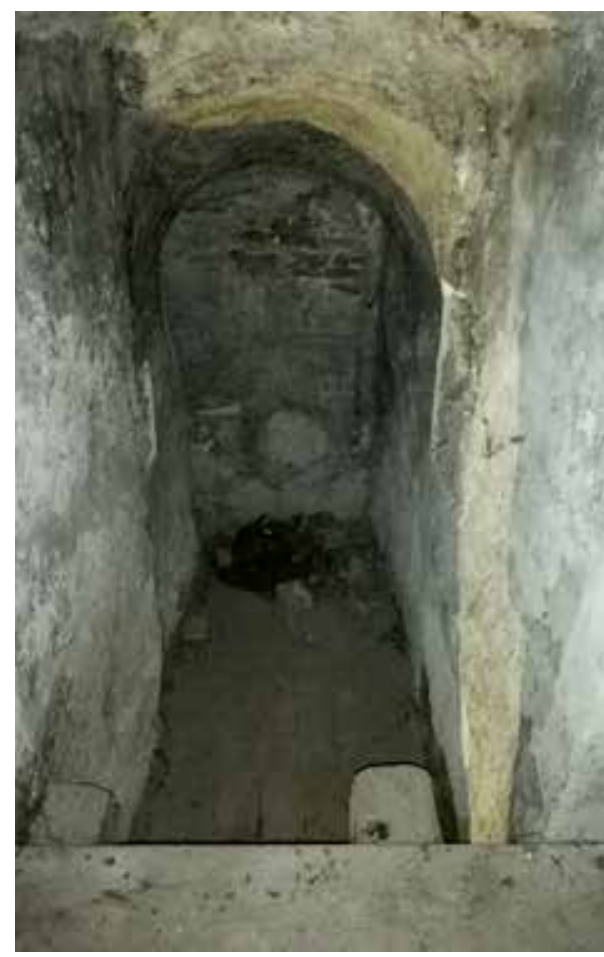

Obr. 7. Bratislava, františkánsky kláštor, priechod vedúci z (pôvodného) prvého poschodia veža do lode kostola (PVI na obr. 3, 4). Foto B. Pomfyová.

Abb. 7. Bratislava, Franziskanerkloster, vom (ursprünglichen) ersten Turmstockwerk ins Kirchenschiff führender Durchgang (PVI auf Abb. 3, 4). Foto B. Pomfyová.

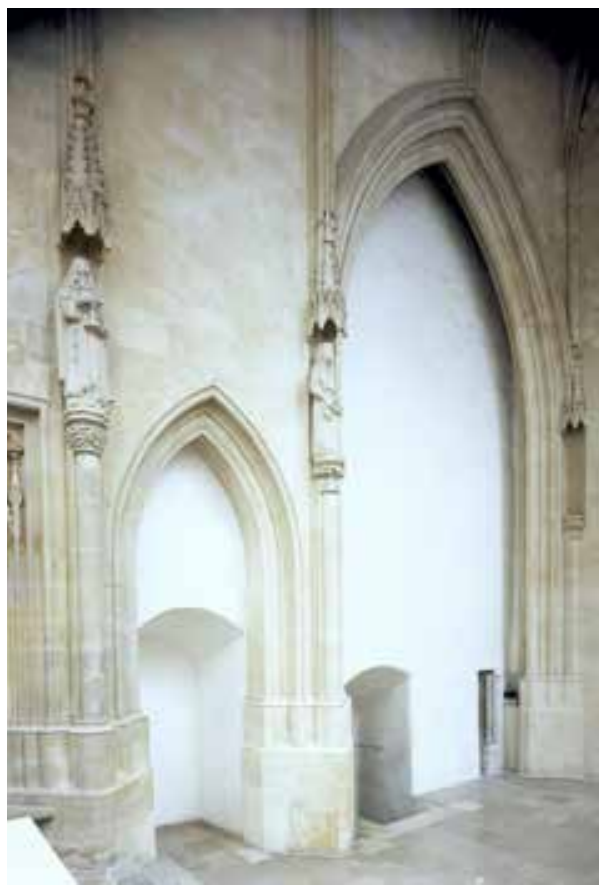

Obr. 8. Bratislava, františkánsky kláštor, Kaplnka sv. Jána na severnej strane kostola, arkády v jej južnej stene. Foto P. Breier, Archív Centra vied o umení SAV - Ústavu dejín umenia.

Abb. 8. Bratislava, Franziskanerkloster, Johanniskapelle an der Nordseite der Kirche, Arkaden in der Kapellensüdwand. Foto P. Breier, Archiv des Zentrums für Kunstwissenschaften der Slowakischen Akademie der Wissenschaften - Institut für Kunstgeschichte.

Vedl’a južného portálu lode vznikol však zrejme ešte v 14. storočí d’alší portál (PIV na obr. 2, 3, 4), ktorý mal tiež na severnej strane prinajmenšom plánovaného pendanta $\mathrm{v}$ mieste, kde je dnes sekundárne osadené kamenné ostenie iného gotického portálu (PV na obr. 2, 3), ktorý zodpovedá väčšej z dvojice arkád v kaplnke (obr. 8). ${ }^{14}$ I túto nezvyčajnú situáciu by mohla vysvetlit' existencia letnera. Je možné, že dve protilahlé dvojice priechodov zabezpečovali komunikáciu rôznym skupinám užívatel'ov kostola. Východnejšia a azda o niečo staršia dvojica portálov mohla byt' ako súčast' letnera ešte súčast'ou liturgického priestoru rehol'níkov, ktorí mali svoje prioritné bohoslužobné miesto v liturgickom chóre (presbytériu) kostola. ${ }^{15}$ Susedné západnejšie portály mohli zase umožňovat' priechod z lode do krížovej chodby a kaplnky návštevníkom kostola. Takéto zdvojené prepojenie východnej časti lode s ambitom a kaplnkou by malo svoje

14 Južný aj sekundárne osadený severný portál sú si tvaroslovne blízke. Majú pomerne plytké kamenné ostenie bez hlavíc (južný s o niečo bohatšou profiláciou) ústiace do lomeného záklenku. Južný z tejto dvojice portálov bol v nepublikovanej dokumentácii datovaný ešte do 14. storočia. Kamenné ostenie severného portálu je podl’a sondážneho prieskumu sekundárne osadené v ranobarokovom murive, situácia v jeho pozícii teda nie je autenticky stredoveká, vytvorenie samotného priechodu z lode do kaplnky však bolo časovo zaradené do druhej polovice 14. storočia (Flaugnatti-Mýtnik-Ciulisová 1998a, nepag., sondy 3, 4, 49, pôdorys - predpokladaná etapizácia výstavby lode). Koncept zdvojeného priechodu z kaplnky smerom do lode, hoci nerealizovaný v plánovanom rozsahu, dokladá napokon i samotná dvojica rozmerných arkád na južnej strane Kaplnky sv. Jána. Na pravé ostenie väčšej (západnejšej) z arkád nadväzuje v múre lode torzo asi nedokončeného profilovaného ostenia. Arkády mali byt' smerom do lode prelomené zrejme v plnom rozsahu, k čomu však bud' nedošlo, alebo, ako predpokladá I. Ciulisová (2000, 80; 2000-2001,383), boli tieto vzdušné otvory po krátkej dobe zamurované.

$15 \mathrm{Na}$ konštrukciu letnera mohla svojimi rozmermi reagovat' aj menšia (východnejšia) z dvojice arkád v Kaplnke sv. Jána. 
odôvodnenie zvlášt' v prípade, ak by mal letner smerom do lode plnú čelnú stenu, tak ako to bolo (prinajmenšom do určitej výšky konštrukcie) v prípade letnera košických dominikánov. ${ }^{16}$ V tomto bode však už ide o čisto hypotetické úvahy, ktoré bude možné d’alej rozvíjat' v prípade, že existenciu letnera $\mathrm{v}$ bratislavskom františkánskom kostole niekedy $\mathrm{v}$ budúcnosti definitívne potvrdí archeologický, prípadne híbkový architektonicko-historický výskum.

\section{Slovenská L’upča, františkáni}

V prípade zaniknutého l'upčianskeho kláštora je otázka letnera spojená s otázkou architektonického vývoja celého kláštorného komplexu, v ktorom zostáva mnoho nejasností (súhrnne Pomfyová-Samuel 2015; Pomfyová 2018, 67-68, 108-110). Preto sa aj hypotézy o letnere viažu $\mathrm{k}$ jeho rôznym častiam.

Z architektúry kláštora založeného pred rokom 1263 (zmienka o gvardiánovi) poznáme len relikty odkryté archeologickým výskumom (obr. 9). Ten odhalil dispozíciu s dvoma nádvoriami. Súčastou zástavby okolo týchto nádvorí boli dve sakrálne stavby - každá prislúchala $\mathrm{k}$ inému nádvoriu. Jedna stála v južnej (juhovýchodnej), druhá v severnej (severozápadnej) časti kláštorného komplexu. Južný kostol bol odkrytý len čiastočne, pretože jeho východná čast' zasahuje na súkromný pozemok, na ktorý nebolo možné výskum rozšírit'. Skúmaná bola pozdížna lod' (cca $7,8 \times 13,7 \mathrm{~m}$ ) s dodatočne pristavanou južnou vežou. V obvodom murive lode boli identifikované dva vstupy - jeden na južnej strane, vedúci z podvežia, druhý na severnej strane, spájajúci kostol $\mathrm{s}$ krížovou chodbou. Pôdorys menšieho severného kostola $(11 \times 5,5 \mathrm{~m})$ bol odkrytý kompletne. Tvorila ho krátka lod' a odsadené pravouhlé presbytérium, v ktorom sa našiel i zvyšok oltára. Vstup do kostola sa nachádzal v západnej stene lode, kde po ňom zostali fragmenty pieskovcového prahu. Tento portál prepájal lod' kostola s d’alším pozdĺžnym priestorom $(12 \times 5,5 \mathrm{~m})$, na ktorý západným smerom nadväzoval ešte jeden malý, priečne pozdĺžny priestor - akási predsieň $(3 \times 5,5 \mathrm{~m})$.

Václav Hanuliak, jeden z autorov tunajšieho archeologického výskumu, vyhodnotil situáciu na lokalite tak, že zástavba okolo severného nádvoria vrátane menšej sakrálnej stavby je mladšia: „Celá táto odkrytá čast' kláštora sa javi ako mladšia, ktorej obvodová hradba bola dodatočne pristavaná k staršej, južnej obvodovej hradbe“ (Hanuliak-Ragač 2000, 234-235). Túto mladšiu čast' kláštora datoval do záveru 14., resp. do 15. storočia a vo vztahu k sakrálnej stavbe v tejto časti konštatoval: „Výskum kostolika (...) nepotvrdil situáciu z 13. alebo 14. storočia“ (Hanuliak-Ragač 2000, 243). Naproti tomu južný kostol, skúmaný práve v tom čase (1998, 1999), datoval „,na základe početných architektonických článkov ,in situ' jednoznačne (...) do 1. polovice 13. stor.“ (tamtiež). O aké architektonické články ide, ale nespresnil. Spolu s Radoslavom Ragačom zvažoval, že jeden z týchto kostolov bol Kostolom sv. Ducha, spomínaným v roku 1340. V listine z uvedeného roku udelil král' Karol Róbert obyvatelom L'upče výsady vrátane práva slobodnej vol'by farára a pri tej príležitosti bol zmienený aj Kostol sv. Ducha ako jednoznačne farský (ut plebanatu ecclesie nostre sancti Spiritus; Juck 1984, 130-131, č. 159). Tým, že ho menovaní bádatelia dali do súvisu s kláštorom, prisúdili mu i funkciu kláštorného kostola, ba čo viac, aj charitatívno-sociálno-liečebnú úlohu - malo íst' o kostol kláštorného špitála (Hanuliak-Ragač 2000, 236, 242). Zvažovali, že by týmto špitálom mohla byt' severná čast' kláštora, čo ale narážalo na chronologický problém: písomná zmienka o Kostole sv. Ducha už v roku 1340, datovanie severnej časti na záver 14., či až do 15. storočia. Ako alternatíva pre stotožnenie s Kostolom sv. Ducha sa tak podl’a nich ponúkala sakrálna stavba v južnej časti kláštorného areálu. Zároveň však s kláštorom v Slovenskej L’upči spojili (v nadväznosti na staršiu historiografiu) aj zmienku o Kostole Panny Márie v pápežskej bule z roku 1323. Pápež Ján XXII. v uvedenej listine vyhovel žiadosti zvolenského župana, magistra Donča, aby smel byt' pochovaný na cintoríne, resp. v hrobke Kostola Panny Márie v L'upči (in coemeterio ecclesiae beatae Mariae de Lupche; RDSL, 472, č. 1086). Podl'a V. Hanuliaka a R. Ragača mal byt' Kostol Panny

16 Plná čelná stena letnera košických dominikánov, v strede prerušená priechodom, sa zachovala do výšky 100 až $120 \mathrm{~cm}$ v priestore pod dnešnou dlažbou lode kostola (Gojdič-Paulusová-Zvedelová 2006, 4; Oriško 2010, 308). 


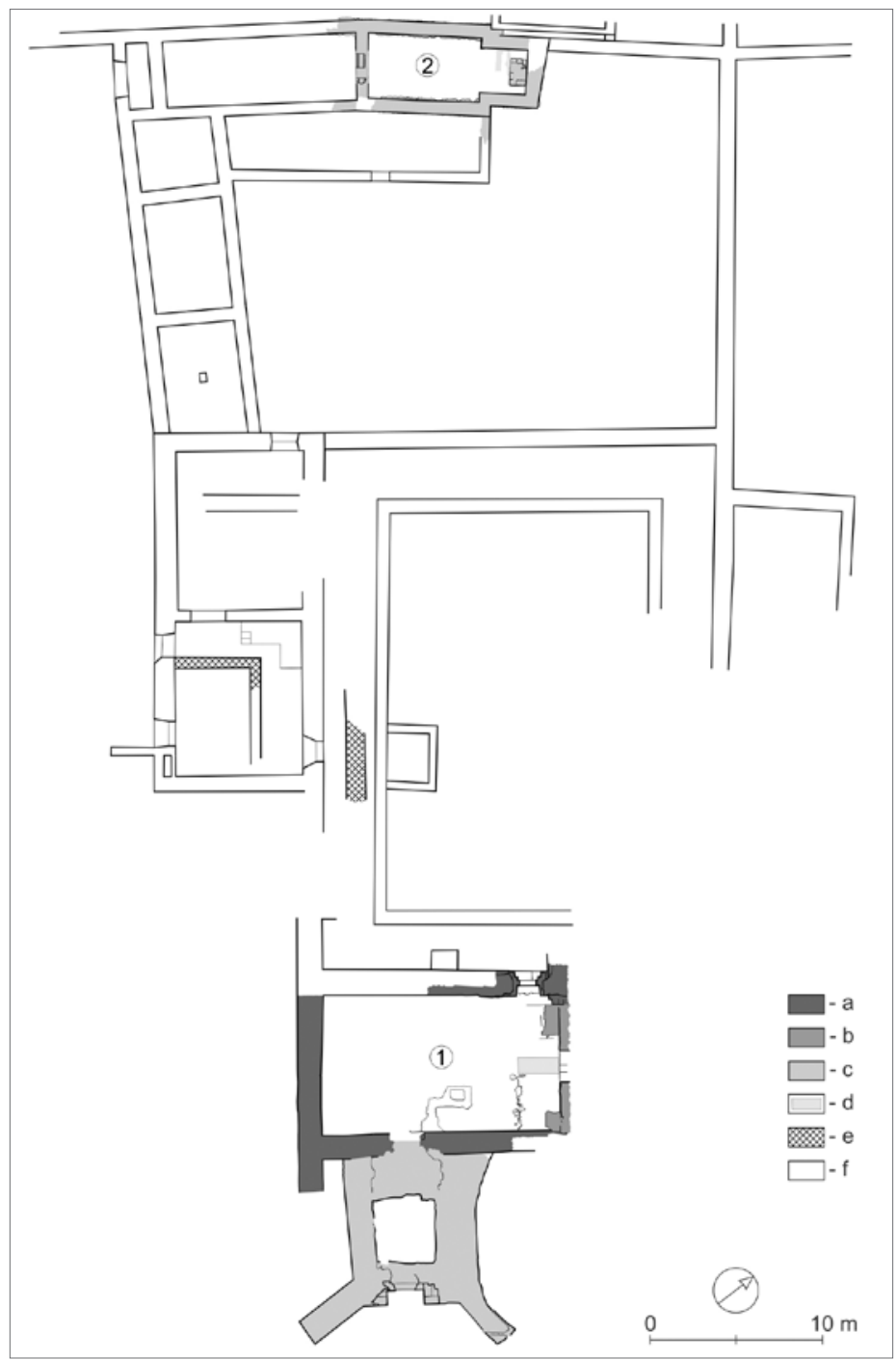

Obr. 9. Slovenská L’upča, zaniknutý františkánsky kláštor, pôdorys: 1 - hlavný kláštorný kostol v juhovýchodnej časti kláštornej dispozície; 2 - kostol v severozápadnej časti kláštornej dispozície; a - archeologicky odkrytá lod' hlavného kláštorného kostola (okolo polovice 13. storočia); $b$ - sekundárne vstavaná chórová priečka (letner?) a zvyšky bočných oltárov v lodi hlavného kláštorného kostola; $c$ - prístavba veže hlavného kláštorného kostola, druhá sakrálne stavba v severozápadnej časti areálu (14. až 15. storočie); d - náhrobná platňa pred portálom v chórovej priečke (letnere); $\mathrm{e}$ - murivá budov, ktoré predchádzali výstavbe verifikovanej kláštornej kvadratúry; f - ostatná, archeologicky odkrytá zástavba zdvojenej kláštornej klauzúry. Podl’a Hanuliak 1989-1999; Hanuliak-Ragač 2000; Mosný 1999; 2000; 2002; Mosný-Selecká 2005; upravené, doplnené.

Abb. 9. Slovenská Lupča, verschwundenes Franziskanerkloster, Grundriss. 1 - Hauptkirche des Klosters im südöstlichen Teil der Klosterdisposition; 2 - Kirche im nordwestlichen Teil der Klosterdisposition; a - archäologisch freigelegtes Schiff der Hauptkirche des Klosters (um Mitte 13. Jhdt.); b-sekundär eingebaute Chorschranke (Lettner?) und Überreste der Seitenaltäre im Schiff der Klosterhauptkirche; c - Turmanbau der Klosterhauptkirche, zweiter Sakralbau im nordwestlichen Teil des Areals (14. bis 15. Jhdt.); d - Grabplatte vor dem Portal in der Chorschranke (im Lettner); e - Mauerwerk der Gebäude, die dem Bau der verifizierten Klosterquadratur vorausgingen; $f$ - sonstige archäologisch freigelegte $B e-$ bauung der doppelten Klosterklausur. Nach Hanuliak 1989-1999; Hanuliak-Ragač 2000; Mosný 1999; 2000; 2002; Mosný-Selecká 2005; bearbeitet, ergänzt. 
Márie „ústredný kláštorný kostol“. Menovaní bádatelia však považovali za málo pravdepodobné, že by ním bola niektorá z dosial' odkrytých sakrálnych stavieb, ked’že usudzovali, že išlo o „monumentálnu viaclod'ovú stavbu, snád' $i$ baziliku" a jej situovanie predpokladali v neodkrytej severovýchodnej časti kláštorného areálu (Hanuliak-Ragač 2000, 243).

Archeologický výskum l'upčianskeho kláštora sa zatial' nedočkal komplexnejšieho publikovaného spracovania. Po V. Hanuliakovi ho viedol Peter Mosný, ktorý pokračoval v skúmaní kostola $\mathrm{v}$ južnej časti kláštora. Jeho interpretáciu posunul v tom, že práve túto sakrálnu stavbu stotožnil s Kostolom Panny Márie. Zotrval na datovaní jej vzniku v prvej polovici 13. storočia a bez bližšej špecifikácie zmienil aj „niektoré neskororománske znaky“ stavby. K úvahám o Kostole sv. Ducha zostal obozretný (Mosný-Selecká 2005, 435; Ruttkay-Mosný 2005, 51-52).

Úplne odlišný pohlad na dva kostoly l’upčianskeho kláštorného areálu prezentoval Š. Oriško. V protiklade s publikovaným datovaním označil za starší kláštorný chrám kostol v severnej časti areálu. Vychádzal z jeho architektonickej dispozície, na základe ktorej ho dal do súvisu so včasnými mendikantskými jednolod’ovými kostolmi s pravouhlým presbytériom. Ako prvý publikoval fragmenty bobul'ových hlavíc, ktoré zaradil do obdobia okolo polovice 13. storočia a nepriamo ich tak dal do súvisu s ním predpokladaným pôvodným kláštorným kostolom. Ďalší kostol v areáli (v južnej časti) mal byt’ podl'a Oriškovej interpretácie novostavbou, ktorú nechal postavit' magister Donč (Oriško 2004, 21). Neskôr svoju interpretáciu ešte doplnil o domnienku, že severný kostol nebol tvorený len krátkym jednolodím a pravouhlým chórom, ale aj d’alšími dvoma priestormi, ktoré naň nadväzovali zo západnej strany. Deliaci múr medzi krátkou lod’ou a bezprostredne nadväzujúcim pozdížnym priestorom, užší než obvodové múry, interpretoval ako pozostatok potenciálneho letnera, rozdel'ujúceho kostol na mníšsku a laickú čast' (Oriško 2010, 307).

Možno súhlasit' so Š. Oriškom, že terén archeológie zostal v prípade l'upčianskeho kláštora v mnohom „,nevyjasnený“. Rámcové datovanie severnej časti areálu na záver 14. až do 15. storočia nebolo podložené žiadnymi chronologicky preukaznejšími nálezmi, čo môže vyvolávat' pochybnosti o jeho časovom zaradení. ${ }^{17}$ Publikované zmienky o architektonických článkoch z prvej polovice 13. storočia či neskororománskych znakoch sú málovravné. Viac svetla do situácie však možno predsa len vniest' na základe dostupnej nepublikovanej dokumentácie (Mosný 1997 až 2002). Z nej vyplýva, že Oriškom publikované fragmenty ranogotických (resp. neskororománskych) bobul'ových hlavíc nesúviseli s kostolom v severnej časti areálu. Našli sa v stavebnej deštrukcii pred severným portálom južného kostola, ktorá okrem iného obsahovala aj zlomky „zapustených stípikov“ (Mosný 1999, 11, 13; 2000, 12-13; 2001, 16). Zo samotného portálu sa zachovala soklová čast'. Dokladá, že portál mal ústupkovú formu, pričom v pravouhlom ústupku bol na každej strane jeden stĺpik s profilovanou prstencovou pätkou; jej horný profil (alebo samotný stĺpik?) bol azda tordovaný - ako možno súdit’ podl’a prierezu zachovaného torza pripomínajúceho ,štylizovaný kvet“ (Mosný 1999, 11, 13; 2000, 12-13; 2001, 16). Ide nepochybne o ,architektonické články ,in situ““ spomínané V. Hanuliakom, resp. „,neskororománske zna$k y^{\text {“ }}$ zmienené P. Mosným. ${ }^{18}$ Tieto architektonické prvky pripúštajú vznik južného kostola pred prvou písomnou zmienkou o kláštore, resp. jeho gvardiánovi z roku 1263. Išlo zrejme skutočne o starší z dvoch kláštorných kostolov, tak ako to konštatoval už V. Hanuliak. Na rozdiel od neho však nemusíme kvôli jednolod'ovej dispozícii pochybovat' o tom, že to bol hlavný kláštorný kostol. Naopak, jednolod’ová dispozícia plne zapadá do obrazu mendikantských kostolov stredovekého Uhorska, ktoré boli prevažne jednolod’ové, prípadne dvojlod’ové, vytvorené zaklenutím na stredoveké piliere. Na prioritný význam tejto stavby poukazujú aj jej väčšie rozmery, prístavba (zrejme mohutnej) veže, zlomky gotickej kameňochárskej výzdoby pochádzajúce z južného portálu alebo veže, doklady pochovávania v interiéri aj exteriéri a d’alšie nálezy. Nešlo však zrejme o Kostol Panny Márie, ani o Kostol sv. Ducha. Najnovšie interpretácie historikov totiž smerujú

17 V interiéri samotného kostolíka v severnej časti areálu boli doložené dva až tri hroby, z ktorých jeden (detský hrob v severozápadnom nároží) obsahoval mincu z roku 1508 (Hanuliak-Ragač 2000, 243).

18 Fotografiu torza portálu publikoval P. Mosný v obecnej monografii z roku 2010, kde datovanie kostola do prvej polovice zdôvodnil práve architektúrou severného portálu, nespresnil však, o ktorý kostol areálu ide (o druhom sa v stručnom texte, podávajúcom vzhladom na charakter publikácie len rámcové informácie, vôbec nezmienil, Mosný 2010,25). 
k tomu, že pravdepodobne ani jeden z týchto kostolov nestál v kláštornom areáli. Kostol sv. Ducha bol azda dnešným farským Kostolom Najsvätejšej Trojice a Kostol Panny Márie, v ktorom chcel byt' pochovaný župan Donč, stál pravdepodobne v Nemeckej (dnešnej Partizánskej), nie Slovenskej L'upči (Marsina 2015, 38, pozn. 24; Meliš 2015, 22-29, 33-34). Patrocínium oboch sakrálnych stavieb i samotného kláštora v Slovenskej L'upči zostáva neisté. Do úvahy prichádza patrocínium sv. Mikuláša, spomínané v novovekých súpisoch kláštorov a farností v Ostrihomskej arcidiecéze (Lipcha, seu Liptoviense. S. Nicolai, Acta et decreta 1667, 119), ${ }^{19}$ alebo sv. Františka, ktoré kláštornému kostolu prisudzuje jedna listina z roku 1559 (Meliš 2015, 29-30).

Južný kostol prešiel podla všetkého viacerými stavebnými úpravami. Spomenutá bola prístavba veže. Na základe exteriérového oporného piliera pristavaného k severnej stene lode a fragmentov klenbových rebier a konzol (Mosný 2000, 14; 2001, 16) možno predpokladat' tiež zaklenutie lode. Sekundárna voči obvodovým múrom lode bola aj priečka, ktorá ohraničovala lod' na východnej strane. Priečku v strede prerušoval priechod široký cca $1,9 \mathrm{~m}$ - jeho pozostatkom je prah vytvorený z troch kamenných segmentov. Po vybudovaní priečky boli steny kostolnej lode i priečky zjednotené novým bielym náterom s mal'bou červených liniek imitujúcich kvádrovanie. Niekedy potom bol na severnej bočnej strane, približne v mieste styku priečky so severnou stenou kostola, vytvorený bočný oltár, z ktorého sa zachoval deštruovaný blok muriva. Podl'a stôp d’alšieho bloku muriva mal svojho pendanta i na južnej strane (Mosný 1999, 11, 12; 2002, 8-9). Celková situácia - priečka vo východnej časti lode nepochybne hlavného kláštorného kostola, prerušená v strede priechodom, pred ňou bočné oltáre - napovedá ovel'a jednoznačnejšie než situácia v severnom kostole areálu, že tu máme dočinenia bud's jednoduchou chórovou priečkou oddel'ujúcou svätyňu od lode, alebo s komplikovanejšou štruktúrou letneru. O akú konštrukciu išlo - či „len“ chórovú priečku alebo letner -, sa dnes nedá povedat', v budúcnosti by to mohol ozrejmit' archeologický výskum zatial' neodkrytej východnej časti kostola. Do celkového kontextu zapadá i nález hrobky vybudovanej z kamenných kvádrov a prikrytej nezdobenou náhrobnou platňou z ružového vápenca, v ktorej ležali ostatky „najmenej troch jedincov“ (Ruttkay-Mosný 2005, 51). Doba uloženia kostier je otázna, boli bez sprievodnej výbavy. Hrobka je však stredoveká, bola vybudovaná zrejme predtým, než došlo k zvýšeniu nivelety v lodi kostola a k vytvoreniu novej liatej maltovej podlahy s červeným náterom, ktorá rešpektovala uloženie náhrobnej platne, posunutej voči samotnej hrobke (Mosný 2000, 6-7; 2001, 6; 2002, 8). Podlaha bola vytvorená zrejme koncom 14. až v prvých desat'ročiach 15. storočia. Možno tak usudzovat' na základe analogickej podlahy (liata maltová podlaha so svetločerveným náterom) na prízemí sekundárne pristavanej veže, na ktorej úrovni sa našla minca Žigmunda Luxemburského (1387-1427; Mosný 1997, 4; 1999, 8, 21). Vybudovanie hrobky je teda potrebné predpokladat' najneskôr v tomto období. Vzhl'adom na centrálne umiestnenie hrobky v pozdížnej osi kostola, in medio ecclesiae, musela byt' určená pre prominentnú osobu (osoby) - duchovného stavu alebo významného donátora (donátorov). Situovanie hrobky v stredovej osi a zároveň pred letnerom nebolo v prípade význačných osôb neobvyklé. A ked’že hrobka bola situovaná zjavne vo vzt'ahu $\mathrm{k}$ stredovému priechodu $\mathrm{v}$ chórovej priečke či letneri, je uvedený časový rámec konca 14 . až začiatku 15. storočia hornou časovou hranicou aj pre datovanie tejto deliacej architektonickej konštrukcie.

Funkcia druhého kostola v severnej časti kláštorného areálu zostáva neobjasnená. Pokial' išlo skutočne o mladšiu sakrálnu stavbu, ktorá vznikla ako súčast' zástavby okolo severného nádvoria, tak ako to vyhodnotili archeológovia, potom možno uvažovat' skôr o klauzúrnej kaplnke (k podrobnejšej argumentácii vo vzt’ahu k celkovej dispozícii kláštora s dvomi nádvoriami Pomfyová 2018, 86-87). Samotné torzá murív, vymedzujúce pôdorys tejto časti kláštora, poskytujú však málo indícií pre spol’ahlivejšie určenie funkcie.

19 Zápis lokality - Lipcha, seu Liptoviense, teda bližšie nešpecifikovaná L'upča, alebo Liptov - ale vzbudzuje pochybnosti a vedie opät' k rôznym výkladom, o akú lokalitu by sa vlastne malo jednat', či o Slovenskú alebo Nemeckú L’upču, alebo dokonca františkánsky kláštor v Okoličnom na Liptove. 


\section{Vel'ký Šariš, augustiniáni-pustovníci}

Kláštor sv. Stanislava, založený pred rokom 1274, je podobne ako kláštor v Slovenskej L’upči zaniknutým komplexom a podobne ako v Lupči je aj tu otázka letnera previazaná s identifikáciou archeologicky odkrytých stavebných reliktov (obr. 10).

V priestore niekdajšieho kláštora (neskôr areálu neskororenesančného kaštiel’a Rákocziovcov, dnes na okraji športového areálu) stojí malá Kaplnka sv. Kunhuty (obr. 12, 13). Tvorí ju jedno obdížnikové klenbové pole a polygonálny (5/8) uzáver. Klenbové rebrá vo vrchole zviazané svorníkmi zbiehajú na hlavice jednoduchých alebo zväzkových (trojdielnych) valcovitých prípor. Svorníky aj hlavice nesú reliéfnu rastlinnú výzdobu (obr. 14, 15). Lomené okná sú bez kružieb. Portál v západnej stene má lievikovité ostenie bez hlavíc. Na základe týchto architektonických článkov dal Václav Mencl kaplnku štýlovo do súvisu s farským kostolom v Prešove, presnejšie s trojdielnymi klenbovými príporami na severnej stene jeho trojlodia, ktoré časovo zaradil na začiatok druhej štvrtiny 14. storočia. Predpokladal, že kaplnku stavala prešovská stavebná dielňa. Pôvodné určenie kaplnky mu bolo neznáme, pripomínala mu však presbytérium nedokončeného kostola. Kláštor v jej súvislosti nespomenul (Mencl 1967, 12-13). V zhode s Menclovým hodnotením uvádza Súpis pamiatok na Slovensku kaplnku z polovice 14. storočia. Eviduje, že sa okolo nej kedysi nachádzal park rákocziovského kaštiel’a, no kláštor sa ani v Súpise v súvislosti s kaplnkou nespomína (SPS 1969, 396). Poloha kláštora bola totiž dlho neistá.

Potvrdil ju až archeologický výskum v roku 2003. Ten odkryl juhozápadne od kaplnky relikty obdížnikového objektu s vonkajšími rozmermi cca $24 \times 11 \mathrm{~m}$ (autormi výskumu označený ako objekt 1/03). V jeho interiéri zachytil tehlovú dlažbu, d’alej „členitú vnútornú architektúru“ pri východnom múre, ktorý bol v strede prerušený asi $150 \mathrm{~cm}$ priechodom (,portálom“), ako aj tri náhrobné kamene nad ostatkami desiatich jedincov, situované medzi zvyškami spomenutej členitej architektúry, pred „portálom“ vo východnom múre. Hroby sa našli aj na vonkajšej severnej strane objektu (zachytených bolo pät' vrstiev pochovávania tesne nad sebou). Autori archeologického výskumu interpretovali objavenú budovu ako „súčast’ kláštorného komplexu“, kláštorný „trakt“, avšak bez bližšieho určenia jej funkcie. Konštatovali, že „nie je ani dostatok dôkazov na určenie skúmaného traktu ako kláštorného kostola“. Za pravdepodobnú súčast' kláštora považovali aj Kaplnku sv. Kunhuty. Upozornili, že rebrá jej klenby sú pribudované neorganicky k príporám, na základe čoho predpokladali zmenu stavebného majstra alebo zmenu stavebného plánu, ktorý mal priniest’ odklon od projektu väčšej cirkevnej stavby a rýchle preklenutie kaplnky (Miroššayová-Karabinoš 2005, 20-23; Tomášová-Karabinoš 2006, 195).

Priamo na Kaplnku sv. Kunhuty bol zameraný archeologický výskum v roku 2010. Zistil, že prinajmenšom v rovine základov bola kaplnka pristavaná $\mathrm{k}$ staršiemu múru, ktorý predurčil jej západnú fasádu. Zvyšné obvodové múry vrátane exteriérových oporných pilierov vznikli $\mathrm{v}$ jednej stavebnej etape. Autor výskumu zotrval pri staršom predpoklade, že kaplnka je presbytériom niekdajšieho kláštorného kostola, hoci zistenia výskumu tento predpoklad spochybňovali. Nenašli sa ani stopy predpokladaného triumfálneho oblúka, ani napojenie lode. Výskum však zistil pokračovanie staršieho západného múru severným a južným smerom a narazil tiež na kanál teplovzdušného vykurovania južne od kaplnky (Čurný 2012).

Pochybnosti ohl'adom kaplnky ako presbytéria niekdajšieho kláštorného kostola potvrdil stavebno-historický výskum. V západnej stene kaplnky identifikoval rozhranie staršieho a mladšieho muriva a na tomto rozhraní našiel primárne osadené brvno. Strom, z ktorého brvno pochádza, bol podl’a dendrochronologickej analýzy zot’atý v roku 1543 alebo 1544 . Na základe tohto zistenia bol vyslovený predpoklad, že kaplnka bola s výnimkou staršieho muriva v jej západnej stene vybudovaná až po roku 1544 a pri jej stavbe použili gotické architektonické články zo staršieho zaniknutého objektu, zrejme kláštorného Kostola sv. Stanislava (Petranská 2013).

Hoci si tento predpoklad žiada ešte overenie, hypotézu o tom, že kaplnka bola pôvodne presbytériom väčšieho kláštorného kostola, môžeme definitívne zavrhnút'. Mení to optiku aj na ostatné nálezy, predovšetkým na objekt odkrytý v roku 2003 (objekt 1/03). Domnievam sa, že v prípade tohto objektu ide o kláštorný kostol, presnejšie o jeho lod'. Syntéza doterajších 


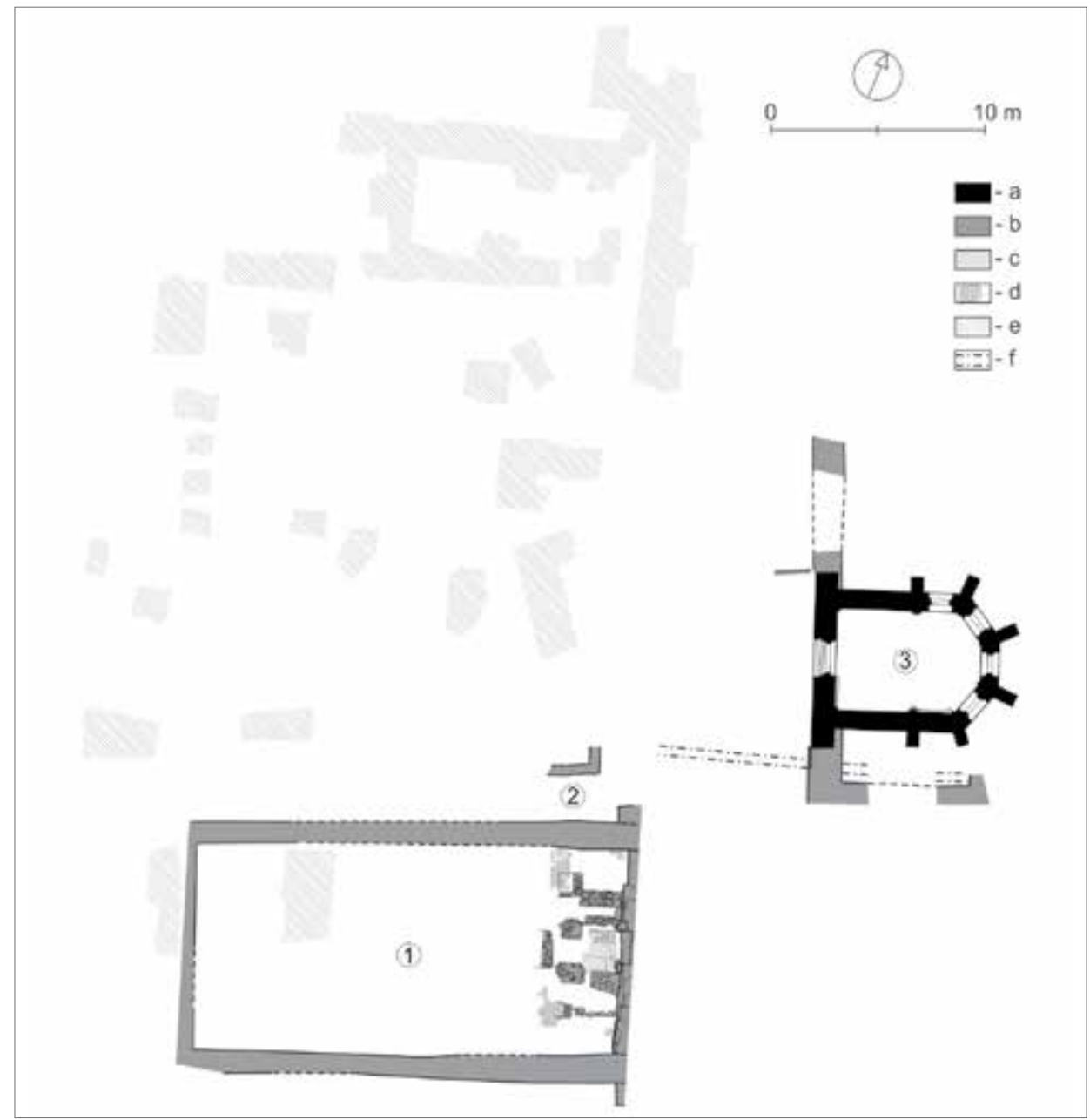

Obr. 10. Vel'ký Šariš, zaniknutý kláštor augustiniánov-pustovníkov, pôdorys: 1 - lod' kostola s predpokladaným letnerom; 2 - krížová chodba; 3 - Kaplnka sv. Kunhuty; a - stojace múry; b-archeologicky odkryté murivá; c - náhrobné platne; d - neskorogotická tehlová dlažba; e - murivá, resp. deštrukcie indikované geofyzikálnou prospekciou; f - hypokaustum. Zdroje Miroššayová-Karabinoš-Tomášová 2004; Čurný 2012; Archív Pamiatkového úradu SR, Zbierka projektov a plánov, sign. V4477; upravené, dopInené.

Abb. 10. Vel'ký Šariš, verschwundenes Augustiner-Eremitenkloster, Grundriss. 1 - Kirchenschiff mit mutmaßlichem Lettner; 2 - Kreuzgang; 3 - Kunigundenkapelle; a - stehende Mauern; b - archäologisch freigelegtes Mauerwerk; c - Grabplatte; d - spätgotische Ziegelsteinpflasterung; e - Mauerwerk, bzw. durch geophysikalische Prospektion indizierte Zerstörungsschicht; f - Hypokaustum. Quellen Miroššayová-Karabinoš-Tomášová 2004; Čurný 2012; Archiv des Denkmalamtes der Slowakischen Republik, Pläne- und Projektsammlung, Sign. V4477; bearbeitet, ergänzt.

poznatkov naznačuje, že kostol tvoril južnú čast' (južný trakt) architektonického jadra kláštora (obr. 10). Existenciu d’alších architektúr severným smerom naznačujú murivá zistené archeologickým výskumom i geofyzikálnym meraním (Tirpák 2012, 209-211). Ešte v roku 2003 bolo zachytené pravdepodobne aj nárožie krížovej chodby (objekt 2/03, Miroššayová-Karabinoš-Tomášová 2004, výskumná správa, 5, výkres 5; Tomášová-Karabinoš 2006, 195). Západný múr, ktorý v 16. storočí čiastočne využila novostavba Kaplnky sv. Kunhuty patril zrejme budovám východného kláštorného traktu. 


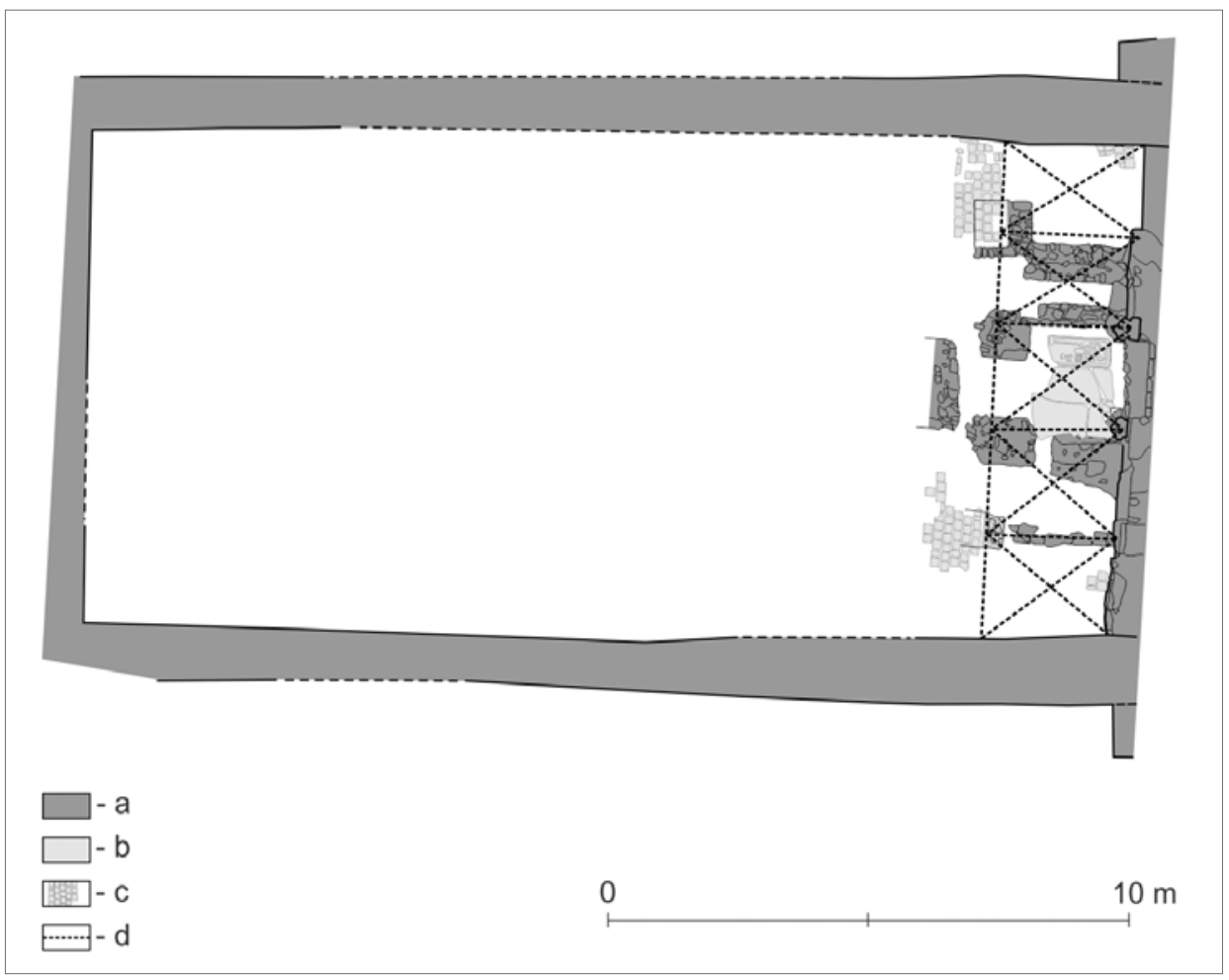

Obr. 11. Vel'ký Šariš, zaniknutý kláštor augustiniánov-pustovníkov, pôdorys lode kostola s teoretickou rekonštrukciou letnera: a - archeologicky odkryté murivá; b-náhrobné platne; $\mathbf{c}$ - tehlová dlažba; $d$ - teoretická rekonštrukcia predpokladanej klenby letnera.

Abb. 11. Vel'ký Šariš, verschwundenes Augustiner-Eremitenkloster, Grundriss des Kirchenschiffs mit theoretischer Rekonstruktion des Lettners. a - archäologisch freigelegtes Mauerwerk; b-Grabplatte; $c$ - Ziegelsteinpflasterung; $d$ - theoretische Rekonstruktion des mutmaßlichen Gewölbes des Lettners.

„Členitá vnútorná architektúra“ vo východnej časti archeologicky odkrytej kostolnej lode bola s najväčšou pravdepodobnost’ou letnerom (obr. 11). Východná stena, nepreviazaná s južným a severným obvodovým múrom lode, tvorila zadnú stenu letnera. Portál v jej strede zabezpečoval priechod medzi lod'ou a zatial' neskúmaným presbytériom (pokračovanie architektúry východným smerom predpokladali aj realizátori archeologického výskumu, čo však nemohli overit', ked’že išlo o súkromný pozemok). Pozostatkom zaniknutého portálu je schodiskový stupeň a prah dlhý $150 \mathrm{~cm}$. Zo strany lode lemovali portál ,pilastre z červeného pieskovca s trojito rebrovaným profilom", vytesané z červeného pieskovca (Miroššayová-Karabinoš 2005, 20). Podla fotografí́ aj pôdorysu v dostupnej nepublikovanej dokumentácii (Miroššayová-Karabinoš-Tomášová 2004, výkres 1 až 4) išlo na každej bočnej strane o príporu tvorenú zväzkom troch valcovitých driekov, na ktoré mohla dosadat' klenba letnera. S ňou mohli súvisiet' aj ,štyri kvadratické pätky stípov murované z kameňov", odkryté pred východnou stenou. Mohlo íst' o stĺpy, ktoré podopierali klenbu letnera zo západnej strany. Určité váhanie síce vzbudzuje skutočnost', že „,koruna väčšiny z nich [pätiek] bola presne lícovaná a pokrytá súvislou vrstvou vápennej malty" ${ }^{20}{ }^{c}$ čo viedlo k domnienke, že nadzemné časti nad pätkami neboli murované, resp. boli postavené z iného materiálu - dreva (Miroššayová-Karabinoš-Tomášová 2004, výskumná

20 Miroššayová-Karabinoš 2005, 20. Podla výskumnej dokumentácie to vzhl'adom na stav zachovania bolo pozorované len v prípade dvoch pätiek (Miroššayová-Karabinoš-Tomášová 2004, výskumná správa, 6). 


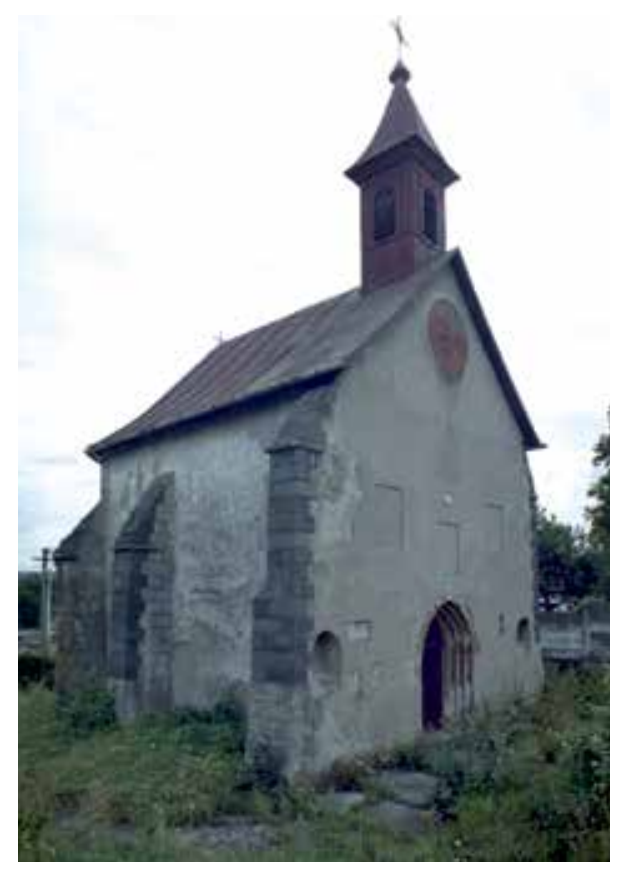

Obr. 12. Vel'ký Šariš, Kaplnka sv. Kunhuty, pohl'ad zo severozápadu. Foto Archív Pamiatkového úradu SR, Zbierka fotografií, sign. 206172.

Abb. 12. Vel'ký Šariš, Kunigundenkapelle, Blick von Nordwesten. Foto Archiv des Denkmalamtes der Slowakischen Republik. Fotosammlung, Sign. 206172. 2 až 4) - v pozdížnej stredovej osi pred predpokladaným letnerom. V tomto prípade môže íst' o pozostatok nie piliera, ale oltára. V takejto pozícii - in medio ecclesiae - býval často umiestňovaný Oltár Svätého kríža, pri ktorom sa o.i. konali verejné omše pre laikov, ktorí nemali prístup $\mathrm{k}$ bohoslužbám pri hlavnom oltári v presbytériu.

Podobne ako v Slovenskej Lupči bola aj vo Vel'kom Šariši odkrytá lod' kláštorného kostola uzavretá letnerom, za ktorým sa nachádzalo zatial' nepreskúmané presbytérium.

V reliktoch skúmaného objektu (kostolnej lode) rozlíšili archeológovia tri stavebné fázy. Najstaršiu reprezentovali obvodové múry (lode) a murované základy pätiek. Do jej časového horizontu boli zaradené aj hrobky s náhrobnými kameňmi, a to na základe reliéfnej výzdoby jedného z náhrobkov s ,istou dávkou starobylej krestanskej symboliky“, hoci kamenná konštrukcia jednej z pätiek prekrývala zachovanú výdrevu truhiel pod náhrobnými kameňmi (Miroššayová-Karabinoš-Tomášová 2004, výskumná správa, 7, 9; Miroššayová-Karabinoš 2005, $21,22)$. Druhej stavebnej fáze pripísali „stavebné úpravy na východnom obvodovom múre, $k d e$ bol vsadený portál a viaceré subtílnejšie murivá v interiéri zachytené prevažne už len v deštrukcii“ (Miroššayová-Karabinoš 2005, 22). „Vsadením portálu“ bolo azda myslené osadenie zväzkových prípor po bokoch stredového priechodu, ktoré neboli previazané so samotným múrom. V tretej stavebnej fáze bola podlaha interiéru prekrytá tehlovou dlažbou. V tom čase konštrukcia

21 Opísané boli ako: „dva čiastočne prerušené múry (sektor A, C), ktoré sa kolmo napájajú na kratši obvodový múr [východný múr] a dve ostenia, resp. prahy z podlhovastých z jednej strany lícovaných pieskovcov. Ostenie a múr v sektore C spájali dve naprieč položené pieskovcové dosky nepravidelného tvaru, v priestore medzi nimi nad'alej prevláda kamenná deštrukcia, po vybratí ktorej boli odkryté steny kanála“ (Miroššayová-Karabinoš-Tomášová 2004, výskumná správa, 6); „prahy z podlhovastých kameňov s vyplnenými špárami a deštruované múry umiestnené v kontrapozícii na jeho stranách [na stranách portálu vo východnom múre]“ (Miroššayová-Karabinoš 2005, 20); „dva priečne múry, dva prahy (sektor $A-C$ ), nedokončená hrobka (?) s kamennými prekladmi (sektor C) a viacerými stavebnými deštrukciami““ (Tomášová-Karabinoš 2006, 195). 


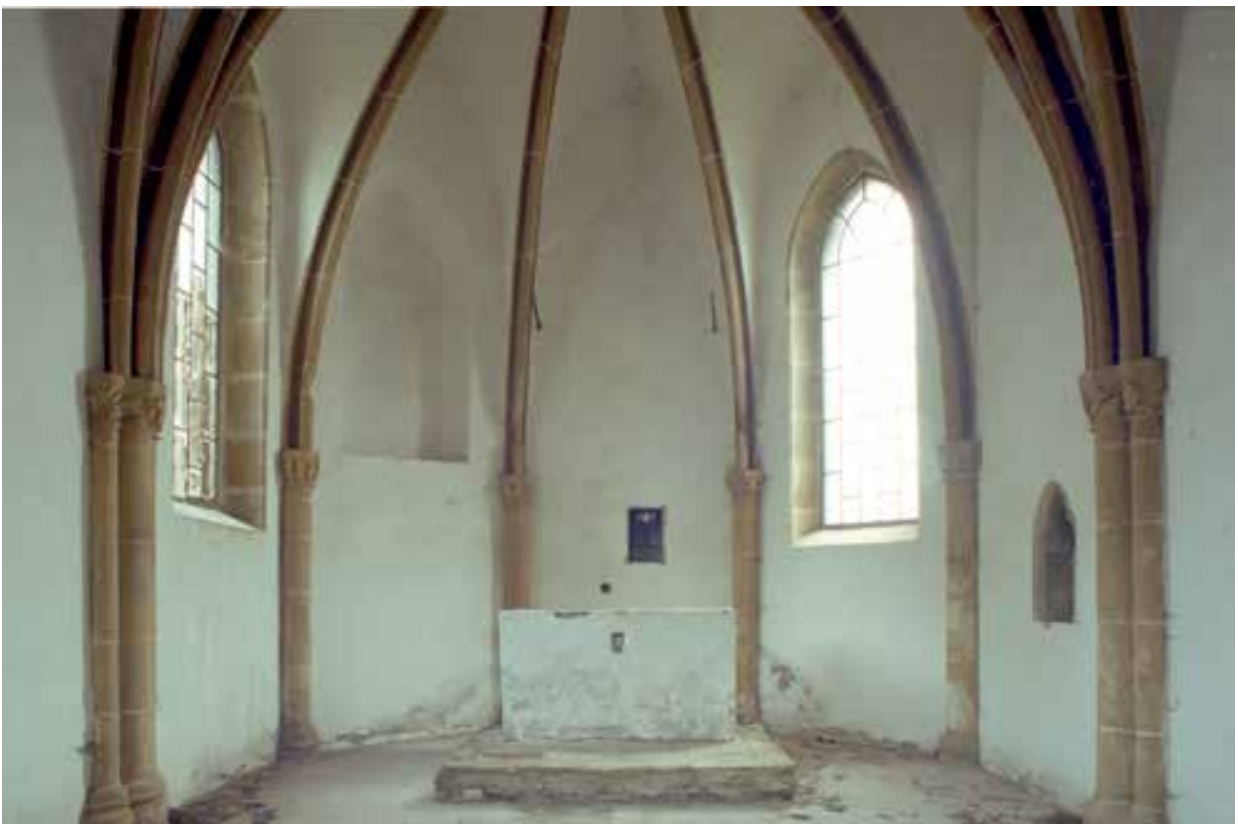

Obr. 13. Vel'ký Šariš, Kaplnka sv. Kunhuty, interiér, pohl’ad k východu. Foto Archív Pamiatkového úradu SR, Zbierka fotografí, sign. 206163.

Abb. 13. Vel'ký Šariš, Kunigundenkapelle, Innenraum, Blick von Osten. Foto Archiv des Denkmalamtes der Slowakischen Republik. Fotosammlung, Sign. 206163.

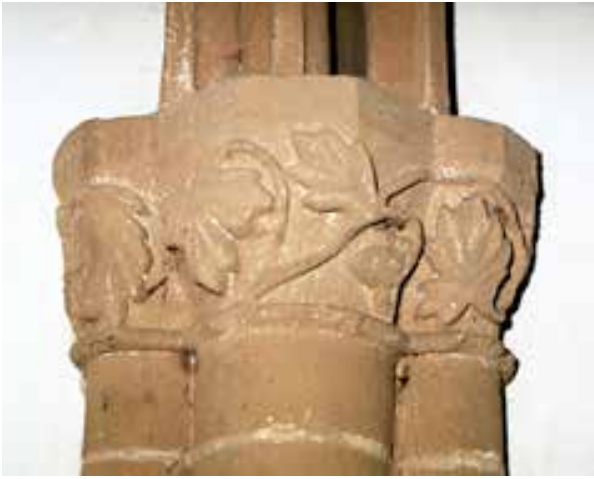

Obr. 14. Vel'ký Šariš, Kaplnka sv. Kunhuty, detail hlavice na zväzkovej klenbovej prípore bočnej steny. Foto Archív Pamiatkového úradu SR, Zbierka fotografí́, sign. 206165. Abb. 14. Vel'ký Šariš, Kunigundenkapelle, Kapitelldetail an einem Gewölbedienstbündel der Seitenwand. Foto Archiv des Denkmalamtes der Slowakischen Republik. Fotosammlung, Sign. 206165.

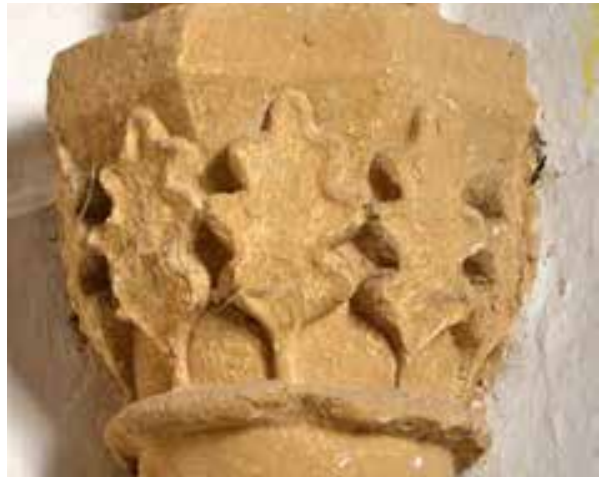

Obr. 15. Vel'ký Šariš, Kaplnka sv. Kunhuty, detail hlavice na valcovitej klenbovej prípore v polygonálnom závere. Foto Archív Pamiatkového úradu SR, Zbierka fotografí́, sign. 206166.

Abb. 15. Vel'ký Šarišs, Kunigundenkapelle, Kapitelldetail an einem zylinderförmigen Gewölbedienst im polygonalen Abschluss. Foto Archiv des Denkmalamtes der Slowakischen Republik. Fotosammlung, Sign. 206166.

letnera zrejme už neexistovala (,,nosné piliere prestali plnit’ funkciu, rovnako tak vnútorné múry a ostenia“, Miroššayová-Karabinoš-Tomášová 2004, výskumná správa, 10).

Autori výskumu datovali jednotlivé fázy len rámcovo. Za termín post quem pre prvú, najstaršiu etapu považovali rok 1274 (nepresne ho považujúc za rok príchodu, resp. usadenia sa 
augustiniánov - pustovníkov vo Vel'kom Šariši; Miroššayová-Karabinoš 2005, 18, 20), prípadne uvažovali o datovaní tejto fázy do konca 13. storočia (Miroššayová-Karabinoš-Tomášová 2004, výskumná správa, 7). „Členitú architektúru“ v interiéri (2. stavebná fáza) zaradili predbežne do prelomu 14. a 15. storočia (Miroššayová-Karabinoš-Tomášová 2004, výskumná správa, 6), resp. konštatovali, že „tieto stavebné úpravy nemohli byt' pre sporý nálezový materiál (...) presnejšie datované" (Miroššayová-Karabinoš 2005, 20). Tehlovú dlažbu z tretej stavebnej fázy datovali do 15. storočia (Miroššayová-Karabinoš-Tomášová 2004, výskumná správa, 10), resp. na prelom 15. a 16. storočia (Miroššayová-Karabinoš 2005, 20). Neskôr zaradili jednotlivé fázy do nasledujúcich časových rámcov: 1. fáza - od vzniku kláštora v r. 1274 do konca 14. storočia, 2. fáza - 15. a začiatok 16. storočia, 3. fáza - 16. storočie (Tomášová-Karabinoš 2006, 195).

Rámcové a čiastočne sa meniace časové zaradenie jednotlivých fáz sa nemohlo opriet' o chronologicky preukaznejšie archeologické situácie. Chronologicky jednoznačné nálezy hlavne tri mince králov Karola Róberta (1330-1332) a Mateja Korvína (1458-1460, 1465) sa našli iba v zásype hrobiek pred portálom, pričom ,neistá stratigrafia neumožňovala hroby presnejšie datovat" (Miroššayová-Karabinoš 2005, 21; Tomášová-Karabinoš 2006, 195). Autori však azda predsa len poskytli určitý oporný bod pre presnejšie datovanie, ked' zmienili, že „profil portálnych pilastrov v skúmanom objekte“ (BP: profilácia prípor, ktoré lemovali portál vo východnom múre letnera) je identický s profilom pätiek prípor v Kaplnke sv. Kunhuty (Miroššayová-Karabinoš 2005, 23).

Táto spojitost' si žiada návrat k datovaniu architektonických článkov v kaplnke. Vyššie už bolo uvedené, že $\mathrm{V}$. Mencl (a v nadväznosti naňho i d’alší autori) ich slohovo spojil s prešovskou stavebnou dielňou, na základe čoho sa vžilo datovanie okolo polovice 14. storočia. Reliéfna rastlinná výzdoba na architektonických článkoch kaplnky - klenbových svorníkoch a hlaviciach (obr. 13-15) - má však tvaroslovne bližšie k o niečo staršej štýlovej vrstve okolo prelomu 13. a 14. storočia. Viaceré analógie k nej možno nájst' v susedných regiónoch Spiša aj Abova. Napríklad v kostoloch v Danišovciach (obr. 16), Seni, dominikánskeho kláštora v Košiciach (obr. 17; podrobnejšie Pomfyová 2015b, 580). Uvedené paralely dovol'ujú časovo posunút' vznik architektonických článkov v kaplnke asi o polstoročie skôr, než je vžité datovanie. Následne sa to

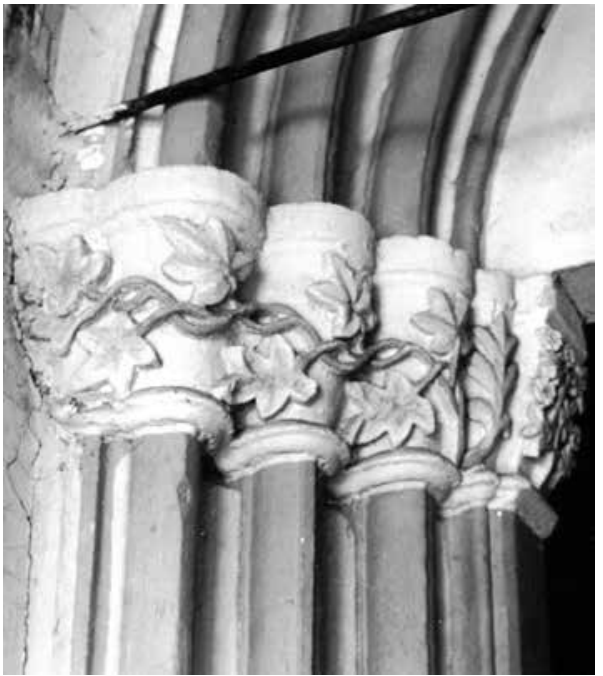

Obr. 16. Danišovce, Kostol sv. Márie Magdalény, detail južného portálu. Foto Archív Pamiatkového úradu SR, Zbierka fotografií, sign. 21529.

Abb. 16. Danišovce, Maria-Magdalenenkirche, Detail des Südportals. Foto Archiv des Denkmalamtes der Slowakischen Republik. Fotosammlung, Sign. 21529. premieta aj do interpretácie archeologických nálezov.

Zhodná profilácia príporových zväzkov v kaplnke a na východnej stene predpokladaného letnera podporuje domnienku, že architektonické články v kaplnke pochádzajú z kláštorného kostola, možno i zo samotného letnera. V každom prípade však indikuje časovú súvislost': druhú stavebnú fázu, identifikovanú archeológmi v skúmanom objekte (kostolnej lodi), je možné datovat' už do doby okolo 1300 , resp. na začiatok 14. storočia, nie až do 15. storočia. Pokial' je správne rozlíšenie jednotlivých fáz zo strany archeológov, potom možno predpokladat', že v tom čase (na prelome 13. a 14. storočia) prešla konštrukcia letnera stavebnou úpravou. Časový odstup medzi prvou a druhou fázou nemusel byt' vel'ký. Treba však korigovat' aj termín post quem pre najstaršiu stavebnú fázu, resp. pre vznik samotného kostola. Nie je ním rok 1274, ked’že ten nie je rokom založenia kláštora, ale prvej zmienky o ňom - král' Ladislav IV. vtedy udelil donáciu podl'a všetkého už existujúcemu 
konventu „bratov Rádu pustovnikov sv. Augustina“ vo Vel'kom Šariši. Pokial' bol kláštor od počiatku zasvätený krakovskému biskupovi Stanislavovi, čo je doložené v roku 1345 (Ordinis Fratrum Villermitarum Sancti Augustini de Claustro S. Stanizlay Martyris), predstavuje terminus post quem rok 1253, ked' bol Stanislav kanonizovaný (o pôvodnosti tohto patrocínia niektorí bádatelia ale pochybujú). Na základe d’alších historických súvislostí vymedzil Miroslav Hut'ka (2015, 123-148) vznik kláštora najnovšie rokmi 1256 až 1266 (1270). V tomto časovom horizonte je teda možné počítat' aj s počiatkami jeho stavebných dejín, hoci jestvujúce poznatky nedovol'ujú zatial' tvrdit', že archeologicky zistená najstaršia stavebná fáza bola prvou $v$ architektonickom vývoji kláštora.

\section{Apendix: chórové priečky a letnery $v$ iných ako mendikantských kostoloch}

Indície pre existenciu chórových priečok a letnerov sa na území Slovenska viažu aj $\mathrm{k}$ iným ako mendikantským kostolom. V zaniknutom, archeologicky skúmanom (farskom?) jednolod'ovom kostole s apsidou v Bíni-Opátskom, vybudovanom zrejme kon-

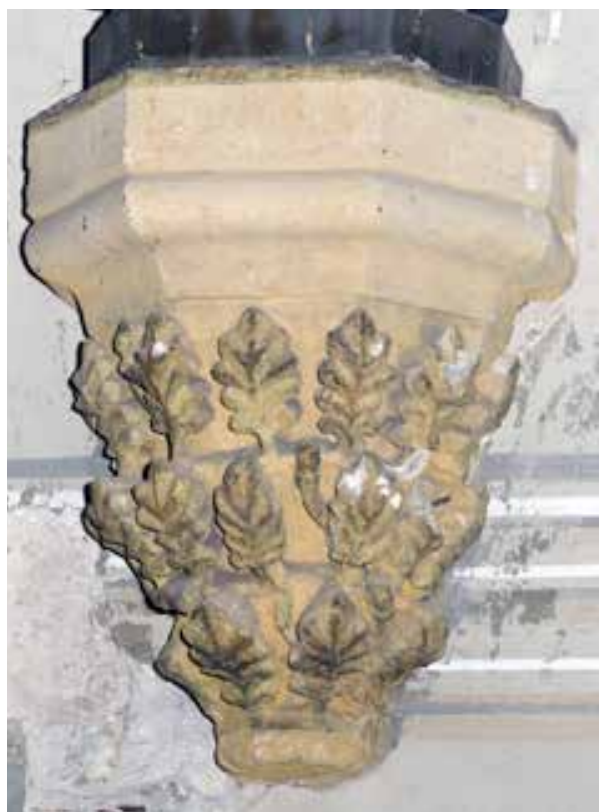

Obr. 17. Košice, dominikánsky kostol, klenbová konzola v presbytériu. Foto P. Breier, Archív Centra vied o umení SAV - Ústavu dejín umenia.

Abb. 17. Košice, Dominikanerkirche, Gewölbekonsole im Chorraum. Foto P. Breier, Archiv des Zentrums für Kunstwissenschaften der Slowakischen Akademie der Wissenschaften - Institut für Kunstgeschichte.

com 11. storočia, indikujú existenciu chórovej priečky zlomky kameňosochársky opracovaného článku (Oriško 2002, 5-12; Pomfyová-Samuel-Žažová 2014, 49-67). V zaniknutom románskom benediktínskom kostole v Krásnej nad Hornádom zachytil archeologický výskum možno zvyšok takejto deliacej konštrukcie na úrovni prvého východného páru medzilod’ových pilierov v trojlodí. Pokial' je tento predpoklad správny, liturgický chór tu zasahoval do najvýchodnejšieho klenbového pol'a hlavnej lode (Pomfyová 2015, 750-751). V d’alšom benediktínskom kostole v Hronskom Beňadiku - v tomto prípade ide o gotickú stavbu zo 14. storočia - je evidentný nábeh priečky alebo letnera na severnom pilieri triumfálneho oblúka, ako aj na protil’ahlom pilieri medzi hlavnou a severnou lod’ou. Deliaca konštrukcia, ktorá tu mala predížit' liturgický chór taktiež prinajmenšom o jedno východné klenbové pole hlavnej lode, bola minimálne plánovaná. O jej dokončení existujú pochybnosti (Takács 2001, 167), či sú oprávnené, môže overit' len archeologický výskum. Deliaca priečka nepochybne členila jednolodie gotického kartuziánskeho kostola na Skale útočiska v Slovenskom raji. Niekedy sa uvádza, že išlo o letner (Slivka s. d., 14), nie je však známe, že by boli zachytené stopy zložitejšej konštrukcie s tribúnou. V prezentovanom stave ruiny sú viditel'né len zvyšky steny so stredovým priechodom, ku ktorej sú zo západnej strany pristavané bočné oltáre. V mendikantských a benediktínskych kostoloch oddel'ovali priečky a letnery liturgický chór od lode, do ktorej mali prístup aj mimokláštorní návštevníci kostola. Naproti tomu kartuziánske kostoly boli pre externých návštevníkov v princípe uzavreté. I tu však mali tieto deliace konštrukcie svoje odôvodnenie - oddel'ovali priestor určený pre chórových mníchov od zvyšku kostola, v ktorej sa k bohoslužbám schádzali konverši, laickí bratia kláštora. V kostoloch tohto prísneho rádu išlo o nepostrádatel'ný prvok, takže je potrebné ho predpokladat' aj v druhom kartuziánskom kláštore - v Červenom Kláštore. Hoci stopy samotnej deliacej konštrukcie tu nie sú evidované (cielený výskum sa zatial' nekonal), celková situácia (situovanie proti sebe umiestnených portálov v bočných stenách kostola, napojenie krížových 
chodieb) tu dokonca dovol'uje uvažovat' o tzv. kartuziánskom letnere (Schmelzer 2004, 98-105) s chodbičkou, ktorá bola pokračovaním vel'kej krížovej chodby a ústila do malej krížovej chodby (obr. 18; Pomfyová 2015a, 354, 356).

V úvode už bolo spomenuté, že letnery sa vyskytovali nielen v kláštorných a kapitulných chrámoch, ale aj vo farských kostoloch rôzneho významu. Na území Slovenska treba o letnere uvažovat' v prvom rade v Kostole sv. Martina v Bratislave, ktorý mal združenú funkciu farského a prepoštského kostola, pri ktorom pôsobilo početné duchovenstvo. Okrem farára, jeho pomocníkov a oltárnikov ustanovených $\mathrm{k}$ jednotlivým oltárom, patril ku kostolu aj zbor kanonikov s každodennou chórovou povinnostou, čo prirodzene zvyšovalo nároky na „chránený“ priestor liturgického chóru. Vo východnej stene severnej bočnej lode sú prelomené dva asymetricky umiestnené otvory - v značnej výške osadený portál a okno (obr. 19). Predpokladá sa, že súviseli s dvojpodlažným priestorom, snád' sakristiou, ktorý mal vypĺn̆at' kút medzi severnou bočnou lod’ou a svätyňou kostola. J. Žáry $(1990,59)$ hypoteticky uvažoval, že portál bol zvnútra prístupný schodiskom a nachádzal sa pred ním balkónik, využívaný aj ako kazatel'nica. Vyvýšený portál však mohol viest' i na tribúnu letnera vo východnej časti trojlodia. Archeologický výskum síce neodkryl murivá, ktoré by mohli byt' interpretované ako zvyšky letnera (Štefanovičová a kol. 2004), východné plochy trojlodia však neboli preskúmané kompletne a letner mohol mat' napokon i drevenú konštrukciu. Existenciu letnera predpokladá v Kostole sv. Martina v obvyklom spojení s Oltárom Svätého kríža aj G. Endrődi (2001, 13, 17). Ďalší významný kostol, ktorý je možné v tejto súvislosti zmienit', je farský Kostol sv. Jakuba v Levoči. Georadarový prieskum zaznamenal v interiéri jeho trojlodia murivá, ktoré sú interpretované ako pozostatky staršieho kostola (Urbanová-Kosová 2016, 110-111, pôdorys na s. 111). Stojí však za zváženie, či niektoré z nich - tie, ktoré boli zachytené pri medzilod'ových pilieroch východných travé - nie sú pozostatkom deliacej konštrukcie - priečky alebo letnera - ohraničujúcej liturgický chór zasahujúci do

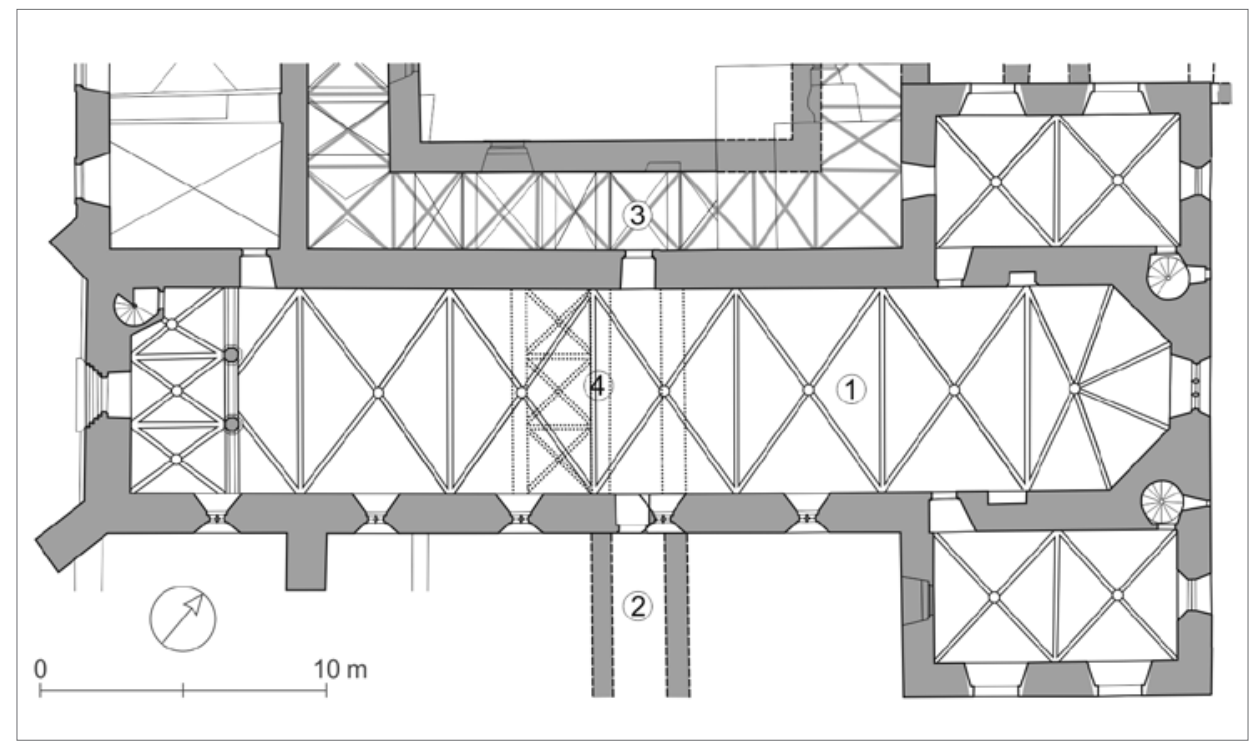

Obr. 18. Červený Kláštor, niekdajší kartuziánsky (neskôr kamaldulský) kláštor, pôdorys kláštorného kostola a pril’ahlých priestorov, bodkovanou líniou naznačené situovanie predpokladaného tzv. kartuziánskeho letnera: 1 - kostol (liturgický chór mníchov); 2 - archeologicky potvrdené napojenie vel’kej krížovej chodby; 3 - malá krížová chodba; 4 - predpokladaný letner. Zdroj Archív Pamiatkového úradu SR, Zbierka projektov a plánov, sign. A1144; upravené, doplnené.

Abb. 18. Červený Kláštor, ehemaliges Kartäuserkloster (später Kamaldulenser), Grundriss der Klosterkirche und der angrenzenden Räume, mit punktierter Linie gekennzeichnete Lage des mutmaßlichen sog. Kartäuserlettners. 1 - Kirche (liturgischer Mönchschor); 2 - archäologisch bestätigter Anschluss des großen Kreuzwegs; 3 - kleiner Kreuzweg; 4 mutmaßlicher Lettner. Quelle Archiv des Denkmalamtes der Slowakischen Republik, Pläne- und Projektsammlung, Sign. A1144; bearbeitet, ergänzt. 


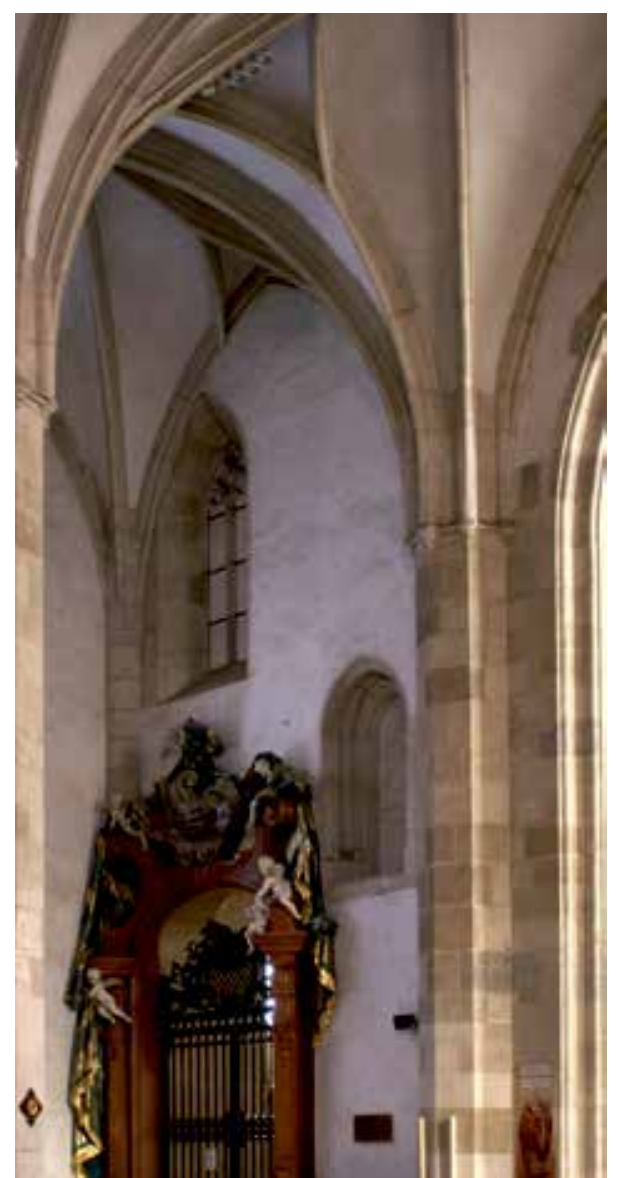

Obr. 19. Bratislava, Kostol sv. Martina, pohl’ad na východnú stenu severnej lode $s$ vyvýšeným gotickým portálom. Foto B. Pomfyová.

Abb. 19. Bratislava, St. Martinskirche, Blick auf die Ostwand des nördlichen Kirchenschiffs mit erhabenem gotischen Portal. Foto B. Pomfyová. priestoru hlavnej lode. Mohlo by to vysvetlit' dve veci: pozoruhodne (vzhl'adom na vel'kost' a význam kostola) krátke presbytérium, ako aj rozdielne rozostupy medzilod'ových pilierov (po troch kratších východných klenbových poliach nasledujú tri dlhšie). Definitívnu odpoved' môže dat' samozrejme opät' až archeologický výskum. Hypoteticky sa o konštrukcii letnera uvažuje na základe najnovších výskumov aj v prípade kostola v Šamoríne, a to v stavebnej etape datovanej do 12. storočia, ked' mal kostol podobu výrazne pozdĺžneho jednolodia s odsadenou polkruhovou apsidou a bočnou južnou kaplnkou (Botek-ErdélyiPauliny-Vachová 2018, 70). Letnery sú však $\mathrm{v}$ tom čase aj $\mathrm{v}$ západoeurópskom prostredí doložené len vo významnejších, kláštorných a katedrálnych kostoloch; príklady vzt'ahujúce sa k dedinským, či menším farským kostolom sú podstatne mladšie. Vzhl'adom na datovanie a kontext dedinského kostola, akým šamorínsky chrám $\mathrm{v}$ tom čase bol, je preto $\mathrm{v}$ tomto prípade zrejme primeranejšie zvažovat' inú interpretáciu. Stopy po konštrukcii vo východnej časti vtedajšej lode, asi $170 \mathrm{~cm}$ od vít’azného oblúka (blok muriva pri dnes už neexistujúcej južnej stene lode, vysekané lôžko $\mathrm{v}$ murive severnej steny) by mohli byt' pozostatkom jednoduchej deliacej priečky alebo ako alternatívne naznačili aj autori architektonicko-historického výskumu - bočných, azda baldachýnových oltárov. Úvaha o letnere sa objavila tiež v súvislosti s kostolom antonitov v Dravciach. Podl'a reštaurátorky Márie Spoločníkovej $(2012,48$, pozn. 4) bola pre letner tohto kostola vytvorená koncom 15 . storočia plastika Ukrižovaného, tvoriaca pôvodne sú-

čast' súsošia Kalvárie. Ide o podnetnú myšlienku osobitne vzhl'adom na kumulované funkcie kostola. Vybudovaný bol na prelome 13. a 14. storočia (zrejme po roku 1288) pre špitálny Rád sv. Antona. Slúžil ako kostol kláštorný, špitálny i farský. Táto kumulácia funkcií podnietila zrejme i výber dispozície predíženého pravouhlého presbytéria, v ktorom sa okrem hlavného oltára nachádzal i liturgický chór rehol’níkov. Členovia rádu usadali k bohoslužbám pozdíž bočných stien v západnej časti presbytéria, tam, kde dodnes stoja dve neskorogotické pät'sedadlové chórové lavice so štítovými znakmi antonitov, vytvorené na začiatku 16. storočia. Lod' kostola (v 14. storočí sekundárne zaklenutá na stredové piliere) bola vyhradená laickej obci, na ktorú boli antoniti zameraní jednak ako ošetrovatelia, a v prípade Draviec aj ako rehol’níci s farskými právomocami (farská funkcia explicitne doložená v roku 1402; Pomfyová-Buran 2015, 382-389). Oddelenie presbytéria od lode prostredníctvom letnera by tu určite malo opodstatnenie. I tu však existenciu takejto deliacej priečky môže overit' len zatial' nerealizovaný archeologický, prípadne architektonicko-historický výskum. V každom prípade slúžia menované kostoly ako príklady interpretačných možností, v rámci ktorých je potrebné uvažovat’ aj o dosial' málo (v domácom výskume) evidovaných špecifických interiérových konštrukciách, ako boli chórové priečky a letnery. 
Táto štúdia vznikla na základe riešenia grantového projektu VEGA 2/0023/16 Stredoveké kláštory žobravých reholí na Slovensku.

Digitalizácia a úprava grafických plánov B. Pomfyová.

\section{Edície prameňov}

ACTA ET DECRETA: Acta et decreta synodi diooecesanae Strigoniensis. Trnava 1667.

CDH: Codex diplomaticus Hungariae ecclesiasticus ac civilis VI/2 (Fejér, G., ed.). Budae 1830.

MES: Monumenta ecclesiae Strigoniensis II (Ferdinandus Knauz, F., ed.). Strigonii 1882.

RDSl: Regesta diplomatica nec non epistolaria Slovaciae II (Sedlák, V., ed.). Bratislava 1987.

\section{Rukopisy a archiválie}

BUREŠ, J., 1965: Středověké stavby slovenských mendikantů. Př́íspěvek k charakteristice slovenské gotiky. Kandidátska dizertačná práca, Bratislava, rkp. ulož. v knižnici Centra vied o umení SAV - Ústavu dejín umenia.

ČURNÝ, M., 2012: Vel'ký Šariš - Kaplnka sv. Kunhuty. Výskumná správa. Košice, rkp. ulož. v Krajskom pamiatkovom úrade Prešov.

FLAUGNATTI, M.-MÝTNIK, V.-CIULISOVÁ, I., 1998: Reštaurovanie nástenných malieb v presbytériu františkánskeho kostola Zvestovania Pána v Bratislave. Bratislava, rkp. ulož. v Archíve Pamiatkového úradu SR, sign. R 3429.

- 1998a: Návrh na reštaurovanie. Reštaurovanie výtvarnej výzdoby stien, klenby a architektonických prvkov interiéru lode františkánskeho kostola Zvestovania Pána v Bratislave. Bratislava, rkp. ulož. v Archíve Pamiatkového úradu SR, sign. R 3485.

- 2001: Lod' bratislavského františkánskeho kostola Zvestovania Pána. Reštaurovanie výmal'by stien, klenby a výtvarno-architektonických prvkov. Záverečná reštaurátorská dokumentácia. Bratislava, rkp. ulož. v Archíve Pamiatkového úradu SR, sign. R 3916.

HANULIAK, V., 1989-1990: Nálezová správa z archeologického výskumu lokality Kláštoriska v kat. úz. Slov. Lupča v rokoch 1989-1990, rkp. ulož. v Krajskom pamiatkovom úrade Banská Bystrica, sign. T 545.

MIROŠŠAYOVÁ, E.-KARABINOŠ, A.-TOMÁŠOVÁ, B., 2004: Výskum Vel'ký Šariš „Na Harminy“, 6. 5. - 8. 12. 2004, rkp. ulož. v Krajskom pamiatkovom úrade Prešove.

MOSNÝ, P., 1997: Slovenská L’upča - Kláštorisko: Nálezová správa z archeologického výskumu za rok 1997. Banská Bystrica, rkp. ulož. v Krajskom pamiatkovom úrade Banská Bystrica, sign. T 500.

- 1999: Slovenská Lupča - Kláštorisko: Nálezová správa z archeologického výskumu za rok 1998. Banská Bystrica, rkp. ulož. v Krajskom pamiatkovom úrade Banská Bystrica, sign. T 503.

- 2000: Slovenská Lupča - Kláštorisko: Nálezová správa z archeologického výskumu za rok 1999. Banská Bystrica, rkp. ulož. v Krajskom pamiatkovom úrade Banská Bystrica, sign. T 536.

- 2001: Slovenská Lupča - Kláštorisko: Nálezová správa z archeologického výskumu za rok 2000. Banská Bystrica, rkp. ulož. v Krajskom pamiatkovom úrade Banská Bystrica, sign. T 549.

- 2002: Slovenská L’upča - Kláštorisko. Nálezová správa z archeologického výskumu za rok 2001. Banská Bystrica, rkp. ulož. v Krajskom pamiatkovom úrade Banská Bystrica, sign. T 557.

RESUTÍK, B., 1999: Františkánsky kostol - archeologický výskum 1999. Nálezová správa. Bratislava, rkp. ulož. v Krajskom pamiatkovom úrade Bratislava, Mestskom ústave ochrany pamiatok Bratislava.

\section{Literatúra}

ANDA, J. M.-PROKOPP, M., 1999: Keszthely - Plébániatemplom (Tájak Korok Múzeumok Kiskönyvtára 225). TKM Egyesület.

BEL, M., 1735: Notitia Hvngariae Novae Historico Geographica. Tomvs Primvs. Viennae Austriae. Dostupné z: http://digital.onb.ac.at/OnbViewer/viewer.faces?doc=ABO_\%2BZ173470906\&order=35\&view=SINGLE, cit. 5. 3. 2019. 
BOTEK, A.-ERDÉLYI, R.-PAULINY, P.-VACHOVÁ, B., 2018: Najstaršie etapy vývoja kostola v Šamoríne, Pamiatky Trnavy a Trnavského kraja 21, 65-72.

BUDAY, P., 2012: K stavebným dejinám františkánskeho kostola v Bratislave, Bratislava - Zborník múzea mesta Bratislavy, 24, 29-52.

CIULISOVÁ, I., 1998: Gotická svätyňa františkánskeho kostola Panny Márie v Bratislave, Umění XLVI, č. $3,174-187$.

- 2000: Stredoveká podoba bratislavského františkánskeho kostola, Ars, č. 1-3, 78-93.

-2000-2001: Stredoveká podoba bratislavského františkánskeho kostola, Studia Archaeologica Slovaca Mediaevalia, č. 3-4, 381-395.

ENDRÖDI, G., 2001: Kapitoly z dejín hlohoveckého reliéfu Narodenia Krista. In: Galéria - Ročenka SNG 2001, 7-41. Bratislava.

GOJDIČ, I.-PAULUSOVÁ, S.-ZVEDELOVÁ, K., 2006: Dominikánsky kostol v Košiciach, Pamiatky a múzeá, č. 4, 2-8.

GONZAGA, F., 1587: De origine seraphicae religionis franciscanae, eiusque prograssibus, de regularis observantiae institutione, forma, administratione ac legibus, admirabilique eius propagatione. Romae. Dostupné z: https://archive.org/details/bub_gb_DPDsCMeP7X0C/page/n4, cit. 20. 3. 2019.

HANULIAK, V.-RAGAČ, R., 2000: Príspevok k problematike existencie kláštorného hospica a Kostola sv. Ducha v Slovenskej Lupči - Klosterhospital und die Kirche des Heiligen Geistes in Slovenská Lupča, AH 25, 233-244.

HUDEC, R., 1999: „Historia domus“ bratislavského františkánskeho konventu, Slovenská archivistika 32, č. 2, 57-66.

- 2009: Františkáni v Bratislave v rokoch 1238-1950. Bratislava.

HUŤKA, M., 2015: Augustiniáni na území stredovekého Slovenska (Uhorska). Ružomberok.

JAVORSKÝ, F., 1997-1998: Levočské kostoly v kontexte dejín mesta, Z minulosti Spiša, č. 5-6, 33-60.

JUCK, L', 1984: Výsady miest a mestečiek na Slovensku (1238-1350). Bratislava.

KROESEN, J. E. A.-STEENSMA, R., 2004: The Interior of the Medieval Village Church - Het Middeleeuwse Dorpskerinterieur. Louvain - Paris - Dudley.

LÁSZAY, J. G., 1994: A szécsényi ferences kolostor építéstörténete a 17. század végéig. In: Koldulórendi építészet a középkori Magyarországon (Haris, A., ed.), 491-516. Budapest.

LESÁK, B.-MUSILOVÁ, M.-HOŠŠO, J., 1997: Archeologické výskumy v historickom jadre Bratislavy. In: AVANS 1995, 124-128. Nitra.

LESÁK, B.-RESUTÍK, B., 2000: Archeologické výskumy a nálezy v historickom jadre Bratislavy. In: AVANS 1999, 65-79. Nitra.

LUKÁČ, G., 1998: Stredoveký kláštor minoritov v Levoči (predbežné výsledky archeologického výskumu v rokoch 1992-1996), Východoslovenský pravek 5, 183-200.

MAJOROSSY, J.-SZENDE, K., 2010: Das Preßburger Protocollum Testamentorum 1410 (1427) - 1529. Teil 1: 1410-1487. Wien - Köln - Weimar.

MARKOVÁ, K., 1978: Archeologický výskum v priestore bývalého františkánskeho kláštora na Pugačevovej ulici v Bratislave. In: AVANS 1977, 159-160. Nitra.

MAROSI, E., 1974: Einige tendenziöse Planänderungen. Beiträge zur Stilgeschichte der ungarischen Architektur des vierzehnten Jahrhunderts, Acta Technica Academiaea Scientiarum Hungaricae 77, č. 1-3, 297-354.

- 1994: A koldulórendi építészet Magyarországon. In: Koldulórendi építészet a középkori Magyarországon (Haris, A., ed.), 39-62. Budapest.

MARSINA, R., 2015: K dejinám Slovenskej L’upče do 17. storočia. In: Prudentissimae dominae nobis honorandae (...). K životnému jubileu profesorky Márie Kohútovej (Duchoňová, D.-Rábik, V., edd.), 30-39. Trnava - Bratislava.

MELIŠ, B. J., OP, 2015: Cirkevné pomery v Slovenskej a Partizánskej (Nemeckej) Luupci, Studia Historica Tyrnaviensia 17, 13-35.

MENCL, V., 1967: Šariš v dejinách gotickej architektúry, Vlastivedný časopis 16, 7-22.

- 1971: Jaroslav Bureš, prom. hist., Středověké stavby slovenských mendikantů, posudek kandidátské disertační práce, Ars 5, č. 1-2, 252-254.

MENCL, V.-MENCLOVÁ, D., 1961: Stavebný vývin Bratislavy. In: Bratislava. Stavebný vývin a pamiatky mesta (Fabiánová, O., ed.). Bratislava.

MIROŠŠAYOVÁ, E.-KARABINOŠ, A., 2005: Kláštor augustiniánov vo Vel'kom Šariši, Pamiatky a múzeá, č. 2, 18-24.

MOSNÝ, P., 2003: Kláštorisko v Slovenskej Lupči, Monumentorum tutela - Ochrana pamiatok 14, 179-183.

- 2010: Najstaršie dejiny l’upčianskej kotliny. In: Slovenská L’upča (Dávid, J.-Debnarová, E.-Dvoranová, M., edd.), 23-26. Banská Bystrica. 
MOSNÝ, P.-SELECKÁ, P., 2005: Kláštor v Slovenskej Luupči - Das Kloster in Slovenská L’upča, AH 30, 435-441.

MUSILOVÁ, M.-LESÁK, B., 1996: Archeologický výskum v záhrade kostola a kláštora františkánov v Bratislave, Pamiatky a múzeá, č. 3, 66-67.

ORTVAY, Th., 1892, 1895, 1903: Geschichte der Stadt Preßburg, zv. I/2, II/1, II/4. Pozsony.

ORIŠKO, Š., 2002: K počiatkom románskeho kameňosochárstva na Slovensku (Najstaršie pamiatky, problémy výskumu), Ars, č. 1-3, 3-48.

- 2004: Prvé stredoveké stavby žobravých reholí na Slovensku, Pamiatky a múzeá, č. 1, 15-22.

- 2010: K problematike letnerov v mendikantskej architektúre na Slovensku, Monumentorum tutela 22 , 306-317.

PAPP, Sz., 2013: Nagyszőlős (Виноградів), plébániatemplom. In: Középkori templomok a Tiszától a Kárpátokig Középkori templomok útja Szabolcsban, Beregben és Kárpátalján (Kollár, T., ed.), 130-147. Nyíregyháza.

PETRANSKÁ, D., 2013: Kaplnka sv. Kunhuty vo svetle nových výskumov. In: Moje mesto Vel'ký Šariš, 35-36. Prešov.

POLLA, B.-VALLAŠEK, A., 1991: Archeologická topografia Bratislavy. Bratislava.

POMFYOVÁ, B., 2015: Ranostredoveké kláštory na Slovensku: torzálna architektúra - torzálne poznatky torzálne hypotézy - Frühmittelalterliche Klöster in der Slowakei: torsale Architektur - torsale Erkenntnisse - torsale Hypothesen, AH 40, 733-777.

- 2015a: Červený Kláštor (okr. Kežmarok). Bývalý kartuziánsky Kláštor Panny Márie, sv. Jána Krstitel’a a sv. Antona Pustovníka. In: Stredoveký kostol - historické a funkčné premeny architektúry, zv. I (Pomfyová, B., ed.), 352-371. Bratislava.

- 2015b: Vel'ký Šariš (okr. Prešov). Zaniknutý Kláštor sv. Stanislava rádu augustiniánov - pustovníkov. In: Stredoveký kostol - historické a funkčné premeny architektúry, zv. I (Pomfyová, B., ed.), 578-581. Bratislava.

- 2018: Stredoveká architektúra žobravých reholí na Slovensku - stav výskumu a problémové okruhy. In: Architektúra kláštorov a rehol'ných domov na Slovensku: Dejiny a pamiatková ochrana (Kvasnicová, M.Šeregi, M., edd.), 47-137. Bratislava.

POMFYOVÁ, B.-BURAN, D., 2015: Dravce (okr. Levoča). Bývalý kláštorný a farský kostol zaniknutého antonitského Kláštora sv. Antona Pustovníka (dnes filiálny Kostol sv. Alžbety). In: Stredoveký kostol historické a funkčné premeny architektúry, zv. I (Pomfyová, B., ed.), 578-581. Bratislava.

POMFYOVÁ, B.-SAMUEL, M., 2015: Slovenská Lupča (okr. Banská Bystrica). Zaniknutý františkánsky kláštor. In: Stredoveký kostol - historické a funkčné premeny architektúry, zv. I (Pomfyová, B., ed.), 528-533. Bratislava.

POMFYOVÁ, B.-SAMUEL, M.-ŽAŽOVÁ, H., 2014: Stredoveká Bíňa. Archeológia - história - architektúra. Bratislava.

RÓMER, F., 1865: Pozsony régészeti müemlékei. In: Pozsony és környéke (Kornhuber, G.-Rakovszky, I.Szekcső, T.-Kanka, K.-Rómer, F., edd.), 245-312. Pozsony.

ROTH, P.-SOJÁK, M., 2001-2002: Výsledky výskumu pri kláštore minoritov v Levoči, Z minulosti Spiša 9-10, 64-77.

RUTTKAY, A. T.-MOSNÝ, P., 2005: Vzt’ah medzi Slovenskou Lupčou a Banskou Bystricou z hladiska genézy stredovekých miest, Acta Historica Neosoliensia 8, 49-56.

SCHMELZER, M., 2004: Der mittelalterliche Lettner. Petersberg.

SLIVKA, M., sine dato: Kláštorisko - Skala útočiska. Vydavatel'svo MTM - Milan Tejbus, 2. vydanie.

SPOLOČNÍKOVÁ, M., 2012: Corpus Christi : poklady gotiky v sochárskom umení východného Slovenska. Trnava.

SPS 1969: Súpis pamiatok na Slovensku, zv. III (Güntherová, A., ed.). Bratislava.

ŠEDIVÝ, J., 2006: Cirkev v stredovekej Bratislave - staré odpovede a nové otázky. In: Kapitoly z dejín Bratislavy (Czoch, G.-Kocsis, A.-Tóth, Á., edd.), 93-126. Bratislava.

ŠTEFANOVIČOVÁ, T. a kol., 2004: Dóm sv. Martina v Bratislave. Bratislava.

TAKÁCS, I., 2001: A garamszentbenedeki temploma és liturgikus felszerelése. In: Paradisum plantavit. Bencés monostorok a középkori Magyarországon - Benedictine Monasteries in Medieval Hungary (Takács, I., ed.), 159-186. Pannonhalma.

TIBENSKÝ, J., ed., 1984: Bratislava Mateja Bela. Bratislava.

TIRPÁK, J., 2012: Stredoveká sakrálna architektúra vo svetle archeogeofyzikálneho výskumu na Slovensku. I. diel. Nitra.

TOMÁŠOVÁ, B.-KARABINOŠ, A., 2006: Objav augustiniánskeho kláštora vo Vel'kom Šariši. In: AVANS 2004, 195-196. Nitra.

TÓTH, S., 2006: Keszthely, ehemalige Franziskanerkirche. In: Sigismundus Rex et Imperator. Kunst und Kultur zur Zeit Sigismundus von Luxemburg 1387 (Takács, I., ed.), 420. Mainz. 
UNTERMANN, M., 1996: Chorschranken und Lettner in südwestdeutschen Stadtkirchen - Beobachtungen zu einer Typologie mittelalterlicher Pfarrkirchen. In: Architektur Geschichten. Festschrift für Günther Binding (Mainzer, U., ed.), 73-90. Köln.

URBANOVÁ, N., 2018: Starý kláštor minoritov v Levoči - novšie poznatky o jeho stavebnom vývoji. In: Najnovšie poznatky z výskumov stredovekých pamiatok na Gotickej ceste II. Zborník Gotická cesta 2/2016 (Kalinová, M., ed.), 127-144. Rožňava - Bratislava.

URBANOVÁ, N.-KOSOVÁ, B., 2016: Rímskokatolícky farský Kostol sv. Jakuba Staršieho - bazilika minor. In: Národné kultúrne pamiatky na Slovensku - Levoča (Urbanová, N.-Kosová, B.-Szerdová-Vel’asová, L., edd.), 110-130. Bratislava.

ŽÁRY, J., 1990: Architektúra. In: Žáry, J.-Bagin, A.-Rusina, I., Dóm sv. Martina v Bratislave, 19-78. Bratislava.

\section{Zusammenfassung}

\section{Lettner in mittelalterlichen Kirchen in der Slowakei. Ein Beitrag zur Baugeschichte von Bettelordenklöstern}

Auf mehrere Bettelordenkirchen in der Slowakei beziehen sich Belege oder Indizien für die ehemalige Existenz eines mittelalterlichen Lettners (Bratislava - Franziskaner, Bratislava - Klarissen, Košice - Dominikaner, Košice - Franziskaner, Slovenská Lupča - Franziskaner, Trnava - Klarissen, Trnava - Dominikaner, Vel'ký Šariš - Augustiner-Eremiten). Eine Identifikation dieser speziellen architektonischen Konstruktion ist aber nicht immer eindeutig. Sie hängt von der Gesamtinterpretation der baulichen Entwicklung der Kirche oder sogar des Klosters ab (falls nicht eindeutig ist, welches Objekt die Klosterhauptkirche war). Die vorliegende Studie konzentriert sich auf drei Problemfälle - auf die Bauten der Franziskaner in Bratislava und in Slovenská Lupča und auf die der Augustiner-Eremiten in Vel'ký Šariš. Der abschließende Teil betrifft die Lettnerproblematik auch außerhalb des Kontextes der Bettelordenarchitektur.

In der bestehenden (1297 eingeweihten) Franziskanerkirche in Bratislava ist die Existenz eines Lettners durch zwei Situationen indiziert: 1) Der hohe massive Sockel eines Triumphbogens könnte Teil der Konstruktion eines Lettners sein, was bedeuten würde, dass man bereits beim Bau der bestehenden Kirche, bzw. ihres Chorraums mit der Existenz eines Lettners zumindest gerechnet hatte. 2) Die Lage des Turms am Ostende des Schiffes (an der Südseite), also in der üblichen Flucht eines Lettners, wirft die Vermutung auf, dass der Zugang zur Tribüne des Lettners durch den Turm gewährleistet war. Diese Vermutung wird noch durch das auf dem Niveau des einstigen ersten Turmstockwerks sekundär gemauerte Portal bekräftigt. Das Portal geht vom Turm aus in Richtung Kirchenschiff und konnte auf die Tribüne des Lettners geführt haben.

Bei der in den neunziger Jahren des 20. Jahrhundert durchgeführten Renovierung der Kirche wurde im Körper des Triumphbogens (auf der Seite des Chorraums) eine ältere Mauer mit Gewölbekonsole entdeckt. Ein weiteres Mauerwerk wurde an der Süd- und Nordseite des Triumphbogens bei der um den Bogen durchgeführten archäologischen Grabung entdeckt. Auch bei diesen Funden wurde bisweilen in Betracht gezogen, dass sie mit der Konstruktion eines Lettners zusammenhängen könnten. Eine gründliche Auswertung der Fundsituationen spricht jedoch eher für die Möglichkeit, dass es sich dabei um Überreste eines älteren Baus (Bauten) handelt, der (die) der heutigen Kirche vorausgingen. Indizien für die Existenz einer älteren Architektur wurden auch bei der im Westteil des Kirchenschiffs durchgeführten archäologischen Grabung erfasst. Ob diese ältere Architektur von den Franziskanern genutzt wurde oder sogar für sie entstanden war, kann nicht entschieden werden, da die historischen Anfänge (Zeit ihrer Ankunft, primäre Lage des Klosters) unklar sind.

Das Franziskanerkloster in Slovenská L’upča wurde vor 1263 gegründet, da in dem Jahr sein Vorsteher (Guardian) erwähnt wird. Der Baukomplex ist verschwunden. Bei der archäologischen Grabung wurde die Disposition des Klosters mit zwei Höfen und zwei Sakralbauten freigelegt, von denen jeder zu einem anderen Hof gehörte. Der eine stand im südöstlichen, der 
andere im nordwestlichen Teil des Areals. In der bisherigen Literatur herrscht keine Einigkeit darüber, welcher dieser Sakralbauten älter war und die Funktion der Klosterhauptkirche erfüllte. Aus der Auswertung der verfügbaren Dokumentation geht jedoch eindeutig folgendes hervor: Um Mitte des 13. Jahrhunderts (vor 1263) wurde die Kirche im südlichen (südöstlichen) Teil des Klosters errichtet. Sie war allem Anschein nach die ältere und Klosterhauptkirche. Bei der archäologischen Grabung wurde nur ihr Schiff freigelegt, das an der Ostseite von einer sekundär errichteten Trennmauer abgeschlossen wurde. In ihrer Mitte befand sich ein Durchgang, und auf der Seite des Schiffs hatte man nach einer gewissen Zeit Seitenaltäre angebaut. Bei ihr handelt es sich höchstwahrscheinlich um den Überrest einer Chorschranke oder eines Lettners. Der Bauzeitpunkt dieses Trennelements wurde nicht genau bestimmt. Der aus der Gesamtsituation sich ergebende Terminus ante quem ist die Wende vom 14. und 15. Jahrhundert.

Das Kloster der Augustiner-Eremiten in Vel'ký Šariš wurde vor 1274 gegründet, da es in dem Jahr zum ersten Mal in den schriftlichen Quellen belegt ist. Auch in diesem Fall handelt es sich um einen verschwundenen Baukomplex. Seine Lage war lange unsicher. Erst durch die archäologische Grabung von 2003 wurde bestätigt, dass er sich in dem Bereich befand, in dem die Kunigundenkapelle steht, von der man gedacht hat, sie könnte ein Überrest der Klosterarchitektur sein. Südwestlich von der Kapelle wurde archäologisch ein größeres rechteckiges architektonisches Objekt freigelegt, dessen Interpretation offen blieb. Aufgrund der derzeitigen Erkenntnisse kann festgehalten werden, dass es sich um das Schiff der Klosterkirche handelt, das an der Ostseite von einem Lettner abgeschlossen wurde. Ursprünglich hat man vermutet, dass die Kirche an der Stelle der Kunigundenkapelle stand und dass die Kapelle ursprünglich ihr Chorraum war. Diese Vermutung wurde weder durch die archäologische Grabung, noch durch eine architektonisch-historische Untersuchung bestätigt. Die Kapelle wurde erst im 16. Jahrhundert errichtet, wobei ihr Gewölbe aus sekundär verwendeten architektonischen Elementen gebildet wurde, die sich ihrem Stil nach zum Zeitraum um die Wende des 13. und 14. Jahrhunderts bekennen. Diese Elemente können von der Klosterkirche (vom Lettner?) stammen. Die Profilierung der Gewölbedienste in der Kapelle entsprechen der Profilierung der Gewölbedienste, die das Portal in der Mitte der Ostwand des Lettners säumten. Auf dieser Grundlage kann auch der Bau des Lettners (bzw. seine mutmaßliche bauliche Veränderung) mit der Zeit um das Jahr 1300, bzw. auf Anfang des 14. Jahrhunderts angesetzt werden.

Der abschließende Teil des vorliegenden Beitrags betrifft die Problematik der Chorschranken und Lettner auch außerhalb des Kontextes der Mendikantenarchitektur, und zwar am Beispiel von Benediktinerkirchen (Krásna nad Hornádom, Hronský Beňadik), Kartäuserkirchen (Letanovce - Skala útočiska / Lapis refugii, Červený Kláštor / Rotes Kloster) und Pfarrkirchen (Bíňa-Opátske?, Bratislava, Levoča, Šamorín), bzw. Kloster- und gleichzeitigen Pfarrkichen (Dravce).

Die vorliegende Studie entstand im Rahmen des Förderprojektes VEGA 2/0023/16 Mittelalterliche Bettelordenklöster in der Slowakei.

Digitalisierung und grafische Bearbeitung der Pläne B. Pomfyová.

Mgr. Bibiana Pomfyová, PhD., Centrum vied o umení Slovenskej akadémie vied - Ústav dejín umenia, Dúbravská cesta 9, 84107 Bratislava, Slovenská republika, Bibiana.Pomfyova@savba.sk 
